\title{
Article
}

\section{Sticky Stock Market Analysts}

\author{
Ibrahim Filiz $^{1, * \mathbb{C}}$, Jan René Judek ${ }^{1}\left(\mathbb{D}\right.$, Marco Lorenz $^{2} \mathbb{D}$ and Markus Spiwoks ${ }^{1}$ \\ 1 Faculty of Business, Ostfalia University of Applied Sciences, Siegfried-Ehlers-Street 1, \\ D-38440 Wolfsburg, Germany; ja.judek@ostfalia.de (J.R.J.); m.spiwoks@ostfalia.de (M.S.) \\ 2 Faculty of Economic Sciences, Georg August University Göttingen, Platz der Göttinger Sieben 3, \\ D-37073 Göttingen, Germany; marco.lorenz@stud.uni-goettingen.de \\ * Correspondence: ibrahim.filiz@ostfalia.de; Tel.: +49-160-3344-078
}

Citation: Filiz, Ibrahim, Jan René Judek, Marco Lorenz, and Markus Spiwoks. 2021. Sticky Stock Market Analysts. Journal of Risk and Financial Management 14: 593. https:// doi.org/10.3390/jrfm14120593

Academic Editor: Goran Buturac

Received: 10 November 2021

Accepted: 3 December 2021

Published: 9 December 2021

Publisher's Note: MDPI stays neutral with regard to jurisdictional claims in published maps and institutional affiliations.

Copyright: (c) 2021 by the authors. Licensee MDPI, Basel, Switzerland. This article is an open access article distributed under the terms and conditions of the Creative Commons Attribution (CC BY) license (https:/ / creativecommons.org/licenses/by/ $4.0 /)$.

\begin{abstract}
Technological progress in recent years has made new methods available for making forecasts in a variety of areas. We examine the success of ex-ante stock market forecasts of three major stock market indices, i.e., the German Stock Market Index (DAX), the Dow Jones Industrial Index (DJI), and the Euro Stoxx 50 (SX5E). We test whether the forecasts prove true when they reach their effective dates and are therefore suitable for active investment strategies. We revive the thoughts of the American sociologist William Fielding Ogburn, who argues that forecasters consistently underestimate the variability of the future. In addition, we draw on some contemporary measures of forecast quality (prediction-realization diagram, test of unbiasedness, and Diebold-Mariano test). We reveal that (a) unusual events are underrepresented in the forecasts, (b) the dispersion of the forecasts lags behind that of the actual events, (c) the slope of the regression lines in the predictionrealization diagram is $<1$, (d) the forecasts are highly biased, and (e) the quality of the forecasts is not significantly better than that of naïve forecasts. The overall behavior of the forecasters can be described as "sticky" because their forecasts adhere too strongly to long-term trends in the indices and are thus characterized by conservatism.
\end{abstract}

Keywords: stock market forecasting; forecasting bias; variability of reality; conservatism of predictors

JEL Classification: D83; D84; D91; G17; G41

\section{Introduction}

Capital market forecasts often show a closer connection to the capital market development of the present than to the capital market development of the future. This phenomenon is known as topically orientated trend adjustment (Andres and Spiwoks 1999). It occurs equally in share price forecasts, interest rate forecasts, exchange rate forecasts, and commodity price forecasts (see, e.g., Filiz et al. 2019; Kunze et al. 2018; Spiwoks et al. 2015; Spiwoks and Hein 2007). A tendency to underestimate the variability of reality could be an important cause (Spiwoks et al. 2015).

The American sociologist William Fielding Ogburn discovers almost 90 years ago that forecasters systematically underestimate the actual variability of reality (Ogburn 1934). He provides a concrete research approach to identify such behavior. Presumably because Ogburn deals with the prognosis of sporting events and not with the prognosis of economic events, he has so far not been noticed by economic research.

During an empirical analysis of the forecasting behavior of experts and lay people, Ogburn (1934) concludes that the variability of reality is consistently underestimated. He traces this back to a tendency which he calls the "conservatism of the predictors". In detail, he is referring to:

1. Unusual events (e.g., a sudden drop in an otherwise rising trendline) are forecasted more seldom than they occur in reality, whereas normal events (e.g., a recently rising trendline continuing to rise) are over-represented in forecasts. 
2. The standard deviation of the forecasts is lower than the standard deviation of the actual events.

3. The extent of the forecasted changes lags behind the scale of the actual changes.

Active investment strategies have been popular since the emergence of modern stock markets (Maxwell and van Vuuren 2019; Lofthouse 1996; Friend and Vickers 1965; Cowles 1933). In order to successfully design active investment strategies such as market timing, stock picking, or index picking, forecasts of future stock market developments are indispensable. New forecasting methods are constantly being discussed: econometric models (Goyal et al. 2021; Chen and Vincent 2016; Welch and Goyal 2008), artificial neural networks (Rajab and Sharma 2019; Atsalakis and Valavanis 2009), artificial intelligence (Mallikarjuna and Rao 2019), capital market simulations with multi-agent models (Yang et al. 2020; Krichene and El-Aroui 2018; Arthur et al. 1997), modelling based on the expectations of capital market agents (Atmaz et al. 2021; Greenwood and Shleifer 2014), and neuro-psycho-economics approaches (Ortiz-Teran et al. 2019; Kandasamy et al. 2016; Werner et al. 2009). However, testing these approaches using ex-post forecasts in an out-ofsample data domain repeatedly leads to apparent forecasting successes that then may not materialize in real ex-ante settings (Kazak and Pohlmeier 2019). When the variability of reality is systematically underestimated, this can contribute towards very costly errors in the field of stock market forecasts. Under certain circumstances, basing active investment strategies on inappropriate stock market forecasts can lead to serious losses and even bankruptcy, when expected returns do not occur. Due to the necessity of reliable forecasts for a successful active investment strategy, stock market forecasting is a dynamic field of research.

The reliability of stock market forecasts is rarely examined. There are many studies on pre-tax profit forecasts (Ramnath et al. 2008), but research on the success of actual ex-ante forecasts in stock prices, stock market indices, or stock market returns are still a rarity. So far, it has not been in the focus of research whether stock market forecasts are characterized by a systematic underestimation of the variability of reality as found by Ogburn (1934). This research gap is even more surprising because the necessary investigation tools have long been available in the form of Theil's prediction-realization diagram and the test for unbiasedness. We raise the question of how successful experts were in forecasting major stock indices (DAX, Dow Jones Industrial Index, Euro Stoxx 50) in the period from 1992 to 2020. We use Ogburn's (1934) examination instruments. But we also go beyond this and use current standard procedures such as the comparison to the naïve forecasts (Diebold-Mariano test) and the unbiasedness test.

The forecasts turn out to be quite unreliable. Indeed, forecasters underestimate the variability of reality. This offers interesting starting points for improving the forecasting process.

\section{Literature Review}

\subsection{Technological Progress in Stock Market Forecasting}

There is a rich literature on the appliance of advanced econometric methodology in the forecasting process in order to identify meaningful predictors for future events. Guo (2006) uses ordinary and dynamic least squares regressions to analyze whether four different variables can be used as predictors for stock returns. The study concludes that the consumption-wealth ratio can indeed be used for statistically significant forecasts. Chen and Vincent (2016) also use different econometric models applied to full-sample approaches and out-of-sample approaches in order to analyze the informational value of different variables for the development of the Standard and Poor's 500 index (S\&P 500) for the period 1964 to 2011. They conclude that the market momentum and the investor sentiment can indeed serve as potential predictors for bear markets. In a similar study, Neely et al. (2014) find that adding technical variables to the commonly used macroeconomic predictors can significantly improve the quality of forecasts for the equity risk premium. 
Welch and Goyal (2008) examine the informative value of 13 frequently used variables such as dividend yields or inflation. In contrast to the researchers mentioned above, they find that none of the 13 variables can be used to predict the S\&P 500 index returns from 1926 to 2004 neither in-sample nor out-of-sample. Quite importantly, they also find that none of the information available at the time of a potential investment decision would have helped to gain an idea of future developments. A couple of years later, the same authors extend their research to 29 additional variables that have been brought up in the discussion in the meantime. In spite of the advances in research methods, they still diagnose a poor usefulness in predicting the equity premium in-sample and out-of-sample (Goyal et al. 2021).

Bahrami et al. (2018) add to the research by finding that even though most variables themselves do not lead to significant forecasts, combining forecasts from individual predictive models significantly improves the quality of stock return forecasts for ten advanced emerging markets across the globe.

Whereas most studies cited above apply OLS regression models, Nyberg (2013) examines the suitability of dynamic binary time series models for predicting the S\&P 500 index between 1957 and 2010. The author concludes that both in-sample and out-of-sample, dynamic binary time series models are able to successfully forecast bull and bear markets.

A very dynamic research area is capital market simulation with multi-agent models. Heterogeneous agents interact with one another on an artificial stock market. Their demand for shares and their supply of shares are brought together in a stock exchange, so that the development of the share prices results from the actions of the individual agents. These in turn observe the development of the share price and adjust their further behavior to the development of the share price. In this way, the special dynamics of interactions on stock markets can be modeled and examined more closely. The artificial stock markets are validated using the stylized facts (e.g., fat tails, gain-loss asymmetry, volatility clustering, volume-volatility correlation). The price patterns of artificial stock markets should correspond to the price patterns of real stock markets.

The first highlight of this research area is the Santa Fe Artificial Stock Market (Arthur et al. 1997). The Frankfurt Artificial Stock Market (Hein et al. 2012) also takes into account a realistic stock exchange mechanism, different communication structures between the agents, and different investment philosophies of the agents. Recently, for example, information asymmetries (Krichene and El-Aroui 2018), memory length and confidence level (Bertella et al. 2014), risk preference (Chen and Huang 2008), tick size systems (Yang et al. 2020), and different types of stocks (Ponta and Cincotti 2018) have been taken into account in artificial stock markets. Artificial stock markets have the significant advantage that extreme events (crashes) can be observed more frequently and can be better analyzed than on real stock markets. The decisive disadvantage of the artificial stock markets is that the models are still too abstract to lead to very concrete share price forecasts.

Another very dynamic research area uses survey data to examine the expectations of capital market players more closely (e.g., Atmaz et al. 2021; Cassella and Gulen 2019; Cassella and Gulen 2018; Greenwood and Shleifer 2014). In some approaches, different types of investors (lay people vs. professionals or contrarians vs. extrapolators) are taken into account. The different expectations of these investor groups are then used to develop models for describing or forecasting share price developments. These approaches appear particularly promising because the special importance of the expectations for capital market events is emphasized. In addition, real capital market data are linked with survey data on the expectations of capital market players in a very differentiated manner. In contrast to the approaches of capital market simulation based on multi-agent models, these research approaches remain close to the observable reality of price formation on the stock markets.

In recent years, there have also been promising results regarding neuro-fuzzy systems used for stock price forecasting. For example, Atsalakis and Valavanis (2009) create a neurofuzzy system that outperforms a traditional "buy and hold"-strategy regarding the Athens and the New York Stock Exchange. Even in a direct comparison to econometric methods, Rajab and Sharma (2019) show that neuro-fuzzy approaches to forecasting the Bombay 
Stock Exchange, CNX Nifty, and S\&P 500 can significantly outperform multiple regression analysis models or generalized autoregressive conditional heteroscedasticity models.

On the other hand, Mallikarjuna and Rao (2019) find that traditional linear and nonlinear models are more accurate at forecasting daily stock market returns of selected indices from developed, emerging, and frontier markets for the period 2000 to 2018 than newly emerged artificial intelligence and frequency domain models. However, neither of the four models nor hybrid approaches provide satisfying results across the markets in their study.

In the field of neuro-psycho-economic approaches, Kandasamy et al. (2016) show that interoception, i.e., the perception of physiological signals from within the body, seems to play a role in the success of professional financial traders. Werner et al. (2009) also show that people with good cardiac perception perform better when choosing between profit and loss options.

In the context of ex-post forecasts in the out-of-sample area, these approaches sometimes show enormous potential. However, many of these approaches have yet to prove their suitability for actual ex-ante forecasts. Their informative value for ex-ante forecasts might be limited due to, for example, differences in estimation risk and low statistical power (Kazak and Pohlmeier 2019).

\subsection{Ex-Ante Stock Market Forecasts}

The actual success of stock market forecasts is thus best checked against real ex-ante forecasts. In the area of interest rate forecasts, the evaluation of continuously published forecasts has a long tradition (Filiz et al. 2021; Fassas et al. 2021; Filiz et al. 2019; Kunze et al. 2017; Miah et al. 2016; Pierdzioch 2015; Baghestani et al. 2015; Oliver and Pasaogullari 2015; Spiwoks et al. 2015). In the area of stock market forecasting, however, there are only a small number of studies that check continuously published stock market forecasts for their reliability (see the synoptic overview in Table 1).

Lakonishok (1980) analyzes forecasts for the S\&P 425 index in the period from 1947 to 1974. He concludes that the reliability of the forecasts does not go recognizably beyond that of naïve forecasts. In this context, a naïve forecast is defined as the assumption that the prevailing value for the variable being forecast at the time the forecast is made will also prevail in the future. In addition, the forecasts are biased and systematically underestimate the returns of the S\&P 425. Dimson and Marsh (1984) analyze the forecasted returns of 206 selected British shares in the period from 1980 to 1981. The authors conclude that the forecasts are successful and can lead to systematic excess returns. Fraser and MacDonald (1993) examine forecasts for the development of the French CAC 40 index in the period from 1984 to 1987. This reveals that the forecasts are less reliable than naïve forecasts. Furthermore, it is evident that the forecasts tend to be oriented towards the present rather than the future.

Spiwoks (2004) and Spiwoks and Hein (2007) consider forecasts for six international share indices (the Dow Jones Industrial Index, the DAX, the FT-SE 100, the CAC 40, MIBtel, and the Nikkei 225) issued in the period from 1994 to 2004. The results are very similar. Almost without exception, the forecast time series exhibit greater forecasting errors than the respective naïve forecast. In addition, they exhibit topically orientated trend adjustment (Andres and Spiwoks 1999). In other words, they reflect the present situation more than anything else, and hardly provide any insights into future trends.

Benke (2006) examines DAX forecasts for the period from 1992 to 2005. He establishes that the forecasters consistently underestimate the extent of the actual changes. Bacchetta et al. (2009) analyze forecasts for the Dow Jones Industrial Index and the Nikkei 225 in the period from 1998 to 2005. The authors conclude that the forecasts are suitable for achieving systematic excess returns. Fujiwara et al. (2013) observe TOPIX forecasts in the years from 1998 to 2010. They argue that the forecasters are too strongly orientated towards their previous forecasts and systematically underestimate the actual trends of the TOPIX. 
Table 1. Synoptic overview of studies on ex-ante stock market forecasts.

\begin{tabular}{|c|c|c|c|c|}
\hline Study & Subject of the Forecast & Methods & Time Scale & Result \\
\hline Lakonishok (1980) & S\&P 425 & $\begin{array}{l}\text { Unbiasedness test with } \\
\text { Theil-Sen estimator, Theil's U, } \\
\text { turning point errors }\end{array}$ & 1947-1974 & - \\
\hline Dimson and Marsh (1984) & Selected British shares & $\begin{array}{l}\text { Comparison of forecast and } \\
\text { actual return via } t \text {-test, } \\
\text { Unbiasedness test }\end{array}$ & 1980-1981 & + \\
\hline Fraser and MacDonald (1993) & CAC 40 & $\begin{array}{l}\text { Unbiasedness test, root mean } \\
\text { squared error }\end{array}$ & 1984-1987 & - \\
\hline Spiwoks (2004) & $\begin{array}{l}\text { Dow Jones Industrial Index, } \\
\text { DAX, FT-SE 100, CAC 40, } \\
\text { MIBtel, and the Nikkei } 225\end{array}$ & $\begin{array}{l}\text { Analysis of turning point errors, } \\
\text { Theil's U, TOTA coefficient }\end{array}$ & 1994-2004 & - \\
\hline Benke (2006) & DAX & $\begin{array}{l}\text { Comparison of absolute } \\
\text { frequencies regarding } \\
\text { forecasting errors, direction of } \\
\text { error, and comparison to naïve } \\
\text { forecasts without statistical test }\end{array}$ & 1992-2005 & - \\
\hline Spiwoks and Hein (2007) & $\begin{array}{l}\text { Dow Jones Industrial Index, } \\
\text { DAX, FT-SE 100, CAC 40, } \\
\text { MIBtel, and the Nikkei } 225\end{array}$ & $\begin{array}{l}\text { Root mean squared relative error, } \\
\text { mean absolute relative error }\end{array}$ & 1994-2004 & - \\
\hline Bacchetta et al. (2009) & $\begin{array}{l}\text { Dow Jones Industrial Index, } \\
\text { and Nikkei } 225\end{array}$ & Log Regression & 1998-2005 & + \\
\hline Fujiwara et al. (2013) & TOPIX & $\begin{array}{l}\text { Augmented Dickey-Fuller test, } \\
\text { ADF-Fisher chi-square test }\end{array}$ & 1998-2010 & - \\
\hline
\end{tabular}

$+=$ Overall, the forecasts are assessed as good; - = overall, the forecasts are assessed as being flawed.

As we want to consider the abilities of professional stock market analysts, experimental studies in which the subjects are asked to make stock market forecasts themselves (e.g., Theissen 2007; De Bondt 1993) are not considered here.

\subsection{Hypotheses}

Capital market forecasts often describe the present rather than the future. Spiwoks et al. (2015) cite the systematic underestimation of the variability of reality as a possible reason for the phenomenon of topically oriented trend adjustments in capital market forecasts. The American sociologist William Fielding Ogburn (1934) is the first to address the systematic underestimation of the variability of reality in predicting future events. He presumes that (1) unusual events (e.g., a sudden drop in an otherwise rising trendline) are forecasted too seldom, that (2) the standard deviation of the forecasts is lower than the standard deviation of the actual events, and that (3) the forecasted changes lag behind the actual changes.

We check whether the forecasts for the German Stock Market Index (DAX), the Dow Jones Industrial Index (DJI) and the Euro Stoxx 50 (SX5E) also show these three properties. In formulating the hypotheses, we assume that the observations made by Ogburn (1934) who investigated forecasts of sporting events also apply to stock market forecasts.

Unlike the DAX, the DJI and the SX5E are price indices. Nevertheless, their long-term development is considered to be non-stationary. Over the long term, a rising trend can be recognized in all three stock indices. To this extent, it is simple to define unusual and normal events. A normal event is an increase in the share price index. An unusual event is a decrease in the share price index. Hypotheses 1 and 2 are therefore: 
Hypothesis 1. Falls in stock market indices are forecasted more seldom than they occur in reality.

Hypothesis 2. The standard deviation of the forecasted changes of the stock market indices is lower than the standard deviation of the actual changes in the indices.

Should the systematical underestimation of the variability of reality be true in our data basis, investors would be exposed to a high risk, as relatively large changes in trends, also negative ones, would not be reflected adequately in the forecasts. The best way to test this assumption is to compute a prediction-realization diagram (Theil 1958) that compares the forecasted relative share price changes to the actual relative share price changes (as described in the Methods section). If the forecast changes are smaller than the actual changes, this leads to a regression line with a slope of $<1$ in the prediction-realization diagram. Hypothesis 3 therefore reads:

Hypothesis 3. The slope of the regression lines in the prediction-realization diagram is lower than one (slope <1).

If the predicted changes lag behind the actual changes and it is thus true that the forecasters are guided by conservatism, the forecasts are not unbiased. This can be verified best by means of the test of unbiasedness using the Mincer-Zarnowitz regression (as described in the Methods section). The use of the unbiasedness test is of particular interest here because it can be used to determine whether the underestimation of the changes in the prognosis object can be viewed as statistically significant. Hypothesis 4 is therefore:

Hypothesis 4. The forecasts prove to be biased.

An assessment of capital market forecasts is incomplete if the forecasts are not compared to the naïve forecasts. In view of the results of previous studies (Spiwoks and Hein 2007; Spiwoks 2004; Fraser and MacDonald 1993; Lakonishok 1980), we expect that the quality of the forecasts will not be significantly better than that of naïve forecasts. If this is the case, investors should by no means consider the forecasts, as the naïve forecast is readily available at any time. Hypothesis 5 is therefore:

Hypothesis 5. The quality of the forecasts is not significantly higher than that of naïve forecasts.

\section{Data Basis}

We evaluate DAX forecasts which were published between 1992 and 2020 in the Handelsblatt newspaper (HB). The forecasts have a forecast horizon of one year. In addition, we evaluate forecasts for the DAX and the Euro Stoxx 50 which were published in the period from 2002 to 2020 in the Frankfurter Allgemeine Zeitung (FAZ). We also analyze forecasts for the Dow Jones Industrial Index which were published between 2004 and 2020 in the FAZ. The time scales differ as we have taken into account all stock price forecasts since the beginning of their publication in order to get more meaningful results. These forecasts have forecast horizons of six and twelve months (Table 2). We provide the dataset used in our study as a Supplementary in an Excel format. The dataset comprises all analyzed forecasts published annually in the Frankfurter Allgemeine Zeitung and Handelsblatt between 1992 and 2020. 
Table 2. Data basis and summary statistics.

\begin{tabular}{|c|c|c|c|c|c|c|c|c|c|c|c|c|}
\hline Source & Subject & Period & $\mathbf{N}$ & $\begin{array}{c}\text { Min } \\
\text { (in \%) }\end{array}$ & $\begin{array}{c}\text { Max } \\
\text { (in \%) }\end{array}$ & $\begin{array}{l}\text { Median } \\
\text { (in \%) }\end{array}$ & $\begin{array}{l}\text { Mean } \\
\text { (in \%) }\end{array}$ & $\mathbf{N}$ & $\begin{array}{c}\text { Min } \\
\text { (in \%) }\end{array}$ & $\begin{array}{c}\text { Max } \\
\text { (in \%) }\end{array}$ & $\begin{array}{l}\text { Median } \\
\text { (in \%) }\end{array}$ & $\begin{array}{l}\text { Mean } \\
\text { (in \%) }\end{array}$ \\
\hline & & & \multicolumn{5}{|c|}{ Forecast Horizon 6 Months } & \multicolumn{5}{|c|}{ Forecast Horizon 12 Months } \\
\hline $\mathrm{HB}$ & DAX & $1992-2020$ & NA & NA & NA & NA & NA & 964 & -25.16 & 72.85 & 8.08 & 8.76 \\
\hline FAZ & DAX & $2002-2020$ & 282 & -33.47 & 18.68 & 3.38 & 2.34 & 402 & -25.16 & 45.20 & 8.14 & 8.94 \\
\hline FAZ & DJI & 2004-2020 & 203 & -21.45 & 23.06 & 1.62 & 1.39 & 259 & -20.24 & 42.43 & 6.07 & 5.95 \\
\hline FAZ & SX5E & $2002-2020$ & 270 & -34.63 & 22.57 & 3.24 & 2.32 & 381 & -20.33 & 36.87 & 7.88 & 8.03 \\
\hline$\Sigma$ & & & 755 & & & & & 2006 & & & & \\
\hline
\end{tabular}

HB = Handelsblatt; FAZ = Frankfurter Allgemeine Zeitung; DAX = German Stock Market Index; DJI = Dow Jones Industrial Index; SX5E = Euro Stoxx 50; $\mathrm{N}=$ number of forecasts issued; Min = minimum; Max = maximum; NA = not available.

In Table 2, we also provide descriptive statistics and show both the minimum and maximum predicted percentage index level changes as well as the median and mean value of the predicted percentage index level changes for the examined data. The descriptive statistics on forecast index level changes in Table 2 are shown in percentages to give a clearer picture of the data. The institutes did not forecast percentage index level changes, but rather the respective index levels. For example, M.M. Warburg \& Co. predicted the DAX index level at the end of the year 2009 at 3600 points. At the time the forecast was issued, the DAX had an index level of 4810.20 points. Thus, the institute forecast the largest price decline of $25.16 \%$. The WGZ-Bank forecast the maximum percentage increase in the index level of the DAX in 2003. While the DAX had an index level of 2892.63 points at the time the forecast was made, the bank forecast a percentage increase of $72.85 \%$ to 5000 points at the end of the year. On average, the institutes forecast an index level increase of the DAX of $8.76 \%$ (median $8.08 \%$ ) in the period considered from 1992 to 2020 (see Table A1 in Appendix A for more detailed descriptive statistics on our data basis). In Figure 1, we provide an overview of the 12-month forecasts examined by showing the mean values of the forecasts, the associated actual index values, and the naïve forecasts.

The forecasts are from private German banks such as Fürst Fugger Privatbank or Bethmann Bank, from German state banks such as Helaba or Bayerische Landesbank, from major German banks such as Deutsche Bank or Commerzbank, and from international banks like Goldman Sachs, J.P. Morgan, or BNP Paribas. For a detailed overview of which institutes published forecasts in which newspaper, see Appendices B and C.

The methods applied by the individual institutions in order to obtain their forecasts are not disclosed. The forecasts are collected by HB and FAZ through annual quantitative surveys. For example, at the end of 2019, the newspapers collected and published forecasts that were drawn up for the middle and the end of 2020.

To the best of our knowledge, an analysis of the quality of actual ex-ante forecasts for the Euro Stoxx 50 has not yet been the subject of the literature (Table 1). Ex-ante forecasts of the Dow Jones Industrial Index and the DAX have also not been considered since 2005. Since then, technological progress has led to the emergence of numerous new forecasting tools and methods, which are discussed in our literature section. Overall, our data basis consists of 2761 forecasts covering a period of time of up to 28 years per time series. We are therefore convinced that an analysis of this data basis is a useful addition to the existing literature on stock market forecasts. 


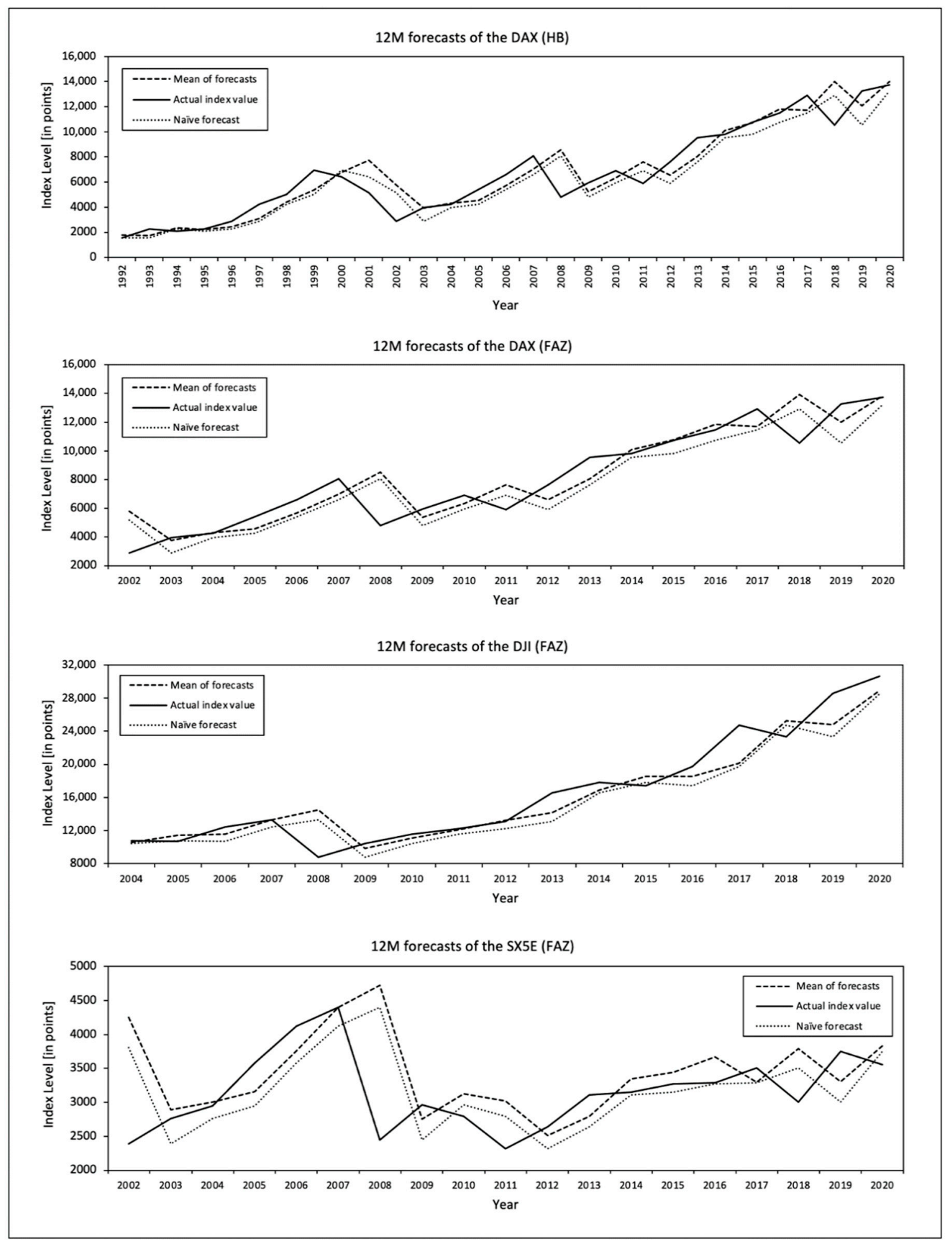

Figure 1. Means of 12M forecasts, actual index values, and naïve forecasts of the DAX, DJI, and SX5E.

\section{Methods}

Fundamentally, we follow Ogburn's assessment of forecasting: Ogburn (1934) assumes that forecasters suffer from conservatism. Therefore, we examine whether (1) unusual events are forecast too infrequently, (2) the standard deviation of the forecasts is lower than the standard deviation of the actual events, and (3) forecast changes lag behind actual 
changes. We consider these three aspects in the forecasts as a whole, but also individually for all forecasters who issue forecasts for at least ten years. In addition, we also go beyond Ogburn's methodology and include some contemporary additions to address the assessment of forecast quality from today's perspective. As statistical tools to measure the quality of the survey-based forecasts we use Theil's prediction-realization diagram (Theil 1958), the test for the unbiasedness of the forecasts, and the Diebold-Mariano test for a comparison to the respective naïve forecast.

We draw on the prediction-realization diagram for a qualitative assessment of forecasting errors. For this purpose, we first calculate the forecasted relative changes $(\rho P F)$ and the realized relative actual stock price changes $(\rho P A)$. $A_{t}$ shows the actual event at the time for which the forecast is applied and $A_{t-h}$ shows the actual event at the time when the forecast was made.

$$
\rho P F=\frac{P_{t}-A_{t-h}}{A_{t-h}} \text { and } \rho P A=\frac{A_{t}-A_{t-h}}{A_{t-h}}
$$

$P=$ forecast of the actual event;

$A=$ actual event;

$t=$ time;

$h=$ forecast horizon.

The forecasted percentage changes and the actual percentage changes are plotted and compared in the prediction-realization diagram (Figure 2). The dashed diagonal line in the prediction-realization diagram reflects the area in which the forecasted percentage changes and the actual realized percentage changes coincide (perfect forecasts). A good forecast time series is therefore characterized by the fact that the values are close to the diagonal. Using an OLS regression, we examine whether the slope of the regression line resulting from the forecasts considered is equal to one. When the variability of actual events is systematically underestimated, the slope of the regression lines in the prediction-realization diagram should be lower than one. A flat course of the regression lines (slope $<1$ ) indicates an underestimation of the actual changes.

For all forecasters who have been taking part in forecasting surveys for at least ten years, we determine the slope of the regression lines individually. All of the other forecasts are evaluated within the framework of the total number of forecasts analyzed and within the framework of the consensus forecasts.

Furthermore, we perform the unbiasedness test using the Mincer-Zarnowitz regression (Mincer and Zarnowitz 1969) to examine whether forecasting errors are systematic. The Mincer-Zarnowitz regression takes the following form:

$$
A_{t}=\alpha+\beta P_{t}+u_{t}
$$

$A_{t}=$ event that actually occurred in time $t$ (dependent variable);

$\alpha=$ constant;

$\beta=$ coefficient of the respective forecast;

$P_{t}=$ forecast of the actual event in time $t$;

$u_{t}=$ error term in time $t$.

Based on this equation, forecasts are considered unbiased if $\alpha$ is not significantly different to 0 , and $\beta$ is not significantly different to 1 . Likewise, the error term $u_{t}$ may not be autocorrelated. Forecasts are considered unbiased when, with a low probability of error, the joint hypothesis of $\alpha=0$ and $\beta=1$ does not have to be rejected. This is checked by using the Wald test (Wald 1943). A further condition is the absence of autocorrelation in the values of the error term $u_{t}$, which is examined with the Wooldridge test (Wooldridge 2002). If, according to these criteria, a forecast time series is unbiased, Granger and Newbold (1974) argue that this by no means signifies that the forecasts are perfect. They merely do not exhibit any systematic errors. 


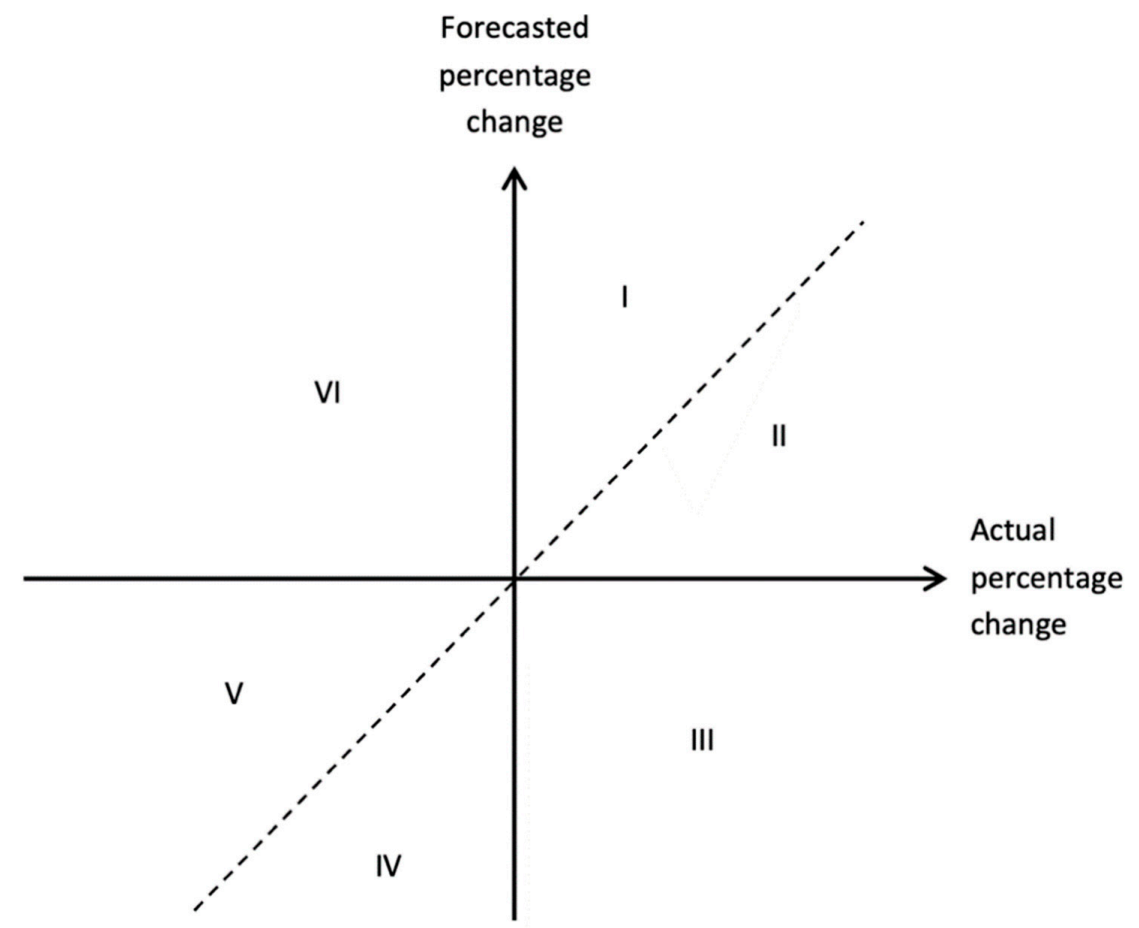

Figure 2. Prediction-realization diagram following Theil (1958). I. The percentage increase of the stock market index is overestimated. II. The percentage increase of the stock market index is underestimated. III. The stock market index rises, although a fall is forecasted. IV. The percentage decrease of the stock market index is overestimated. V. The percentage decrease of the stock market index is underestimated. VI. The stock market index falls, although a rise is forecasted.

Finally, we compare the forecasts with the naïve forecast. A forecaster who has obtained a notable insight into the future trend of the subject matter should at least be able to make more accurate forecasts than if one were to always assume that nothing at all will change (naïve forecast).

Simple measurements of forecast quality (such as the mean absolute squared error or the mean squared error) enable us to make a comparison with a naïve forecast. However, these simple approaches do not permit an assessment of statistical significance. This deficit is remedied by using the Diebold-Mariano test (Diebold and Mariano 1995). To do so, we calculate the mean squared error for the time series of the expert prognoses and for the time series of the naïve forecasts. The test statistics of the Diebold-Mariano test are defined as follows:

$$
D M=\frac{\frac{1}{T} \sum\left(V\left(P_{t 1}\right)-V\left(P_{t 2}\right)\right)}{\sqrt{\hat{\gamma} d / T}}
$$

$T$ = number of observations;

$V=$ loss function;

$P_{1}=$ naïve forecast;

$P_{2}=$ expert forecast; $\sqrt{\hat{\gamma} d / T}=$ joint spread of the two loss functions.

The null hypothesis tested in this way is that the naïve forecast $\left(P_{1}\right)$ and the expert forecast $\left(P_{2}\right)$ have the same accuracy. Neither one of the two alternatives thus provides clearly better results. The numerator is the mean deviation between the loss function $V$ of the two forecasting approaches to be compared. Normally a squared loss function is assumed. In other words, the squared errors of the two forecast approaches are compared $\left(P_{1}\right.$ and $\left.P_{2}\right)$. The denominator is the joint spread of the two loss functions. This is estimated on the basis of the long-term autocovariances of the loss function. In the case of large samples, this test value is asymptotically normally distributed. 
As the methods and variables used by the forecasters in our data basis are not disclosed, we focus on the overall quality of the forecasts in terms of accuracy and unbiasedness. An assessment of the informative value of different forecasting approaches is not in the scope in this study.

\section{Results}

To provide a more detailed insight into our results, we first show the individual forecast quality of two selected German private banks. The graphic representation of the DAX forecasts of the German private bank Berenberg in a prediction-realization diagram indicates that conservative forecasting is at work here (Figure 3).

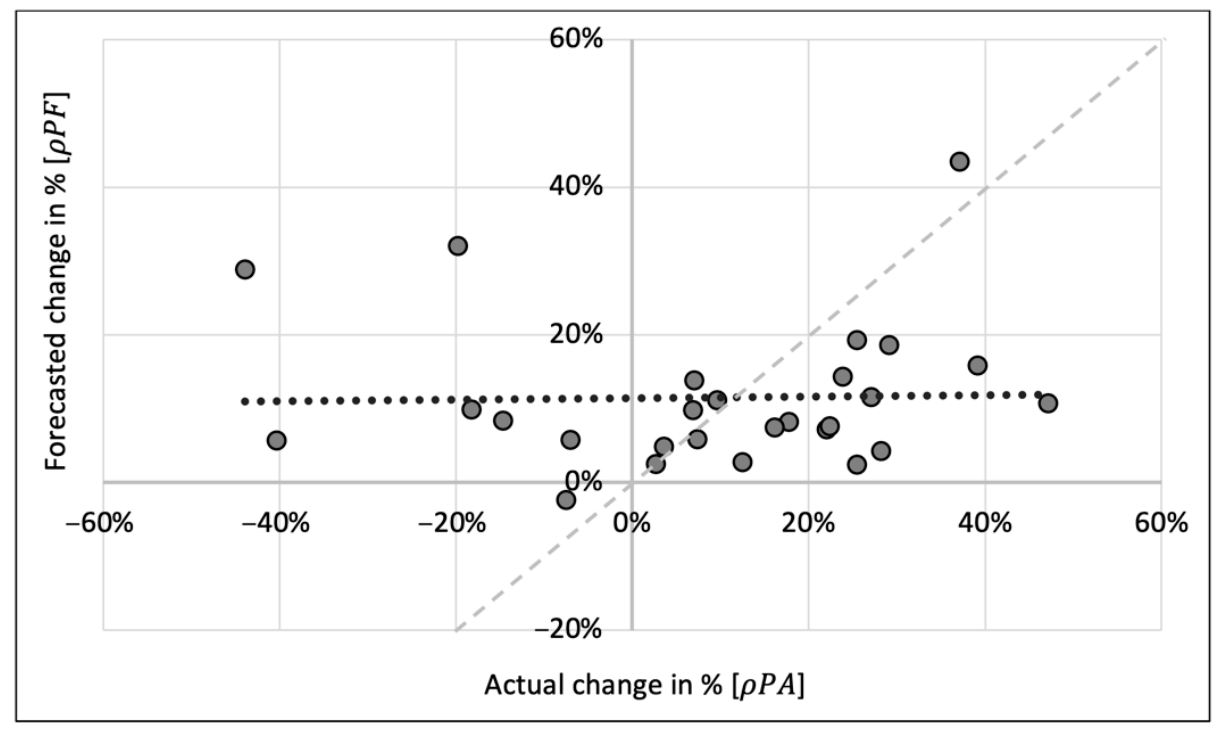

Figure 3. Prediction-realization diagram of the DAX forecasts of Berenberg. Dotted line = regression line; dashed line = perfect forecasts according to the prediction-realization diagram.

Berenberg issued a total of 27 DAX forecasts in the observation period (1992-2020). It is recognizable straight away that only one fall in the DAX is forecasted (3rd quadrant), but that the DAX actually does fall in seven out of the 27 years (3rd and 4th quadrant). This means that unusual events (falls in the DAX) are under-represented in the forecasts.

In addition, it can be seen that the dispersion of the actual events (scattering along the $\rho P A$ axis) is greater than the dispersion of the forecasts (scattering along the $\rho P F$ axis). The standard deviation of the actual events is $22.76 \%$. The standard deviation of the forecasts, however, is only $9.98 \%$ (Table 3 ). The slope in the dotted regression line in the predictionrealization diagram of 0.011 is thus nowhere near the threshold value 1 (dashed diagonal line) (Table 3). The variability of the actual events is dramatically underestimated.

As another example, we consider the prediction-realization diagram of DAX forecasts made by the Franco-German private bank Oddo BHF (Figure 4).

This reveals a picture which is very similar to that of the prediction-realization diagram for Berenberg. In the period 1992-2020, at the end of each year Oddo BHF forecasts the DAX for the coming year. This occurs a total of 28 times. A fall in the DAX is forecasted on three occasions. In reality, however, the DAX falls in eight of the 28 years. This means that unusual events (falls in the DAX) are under-represented in the forecasts. 
Table 3. The main results of the DAX forecasts from 1992 to 2020 from the Handelsblatt.

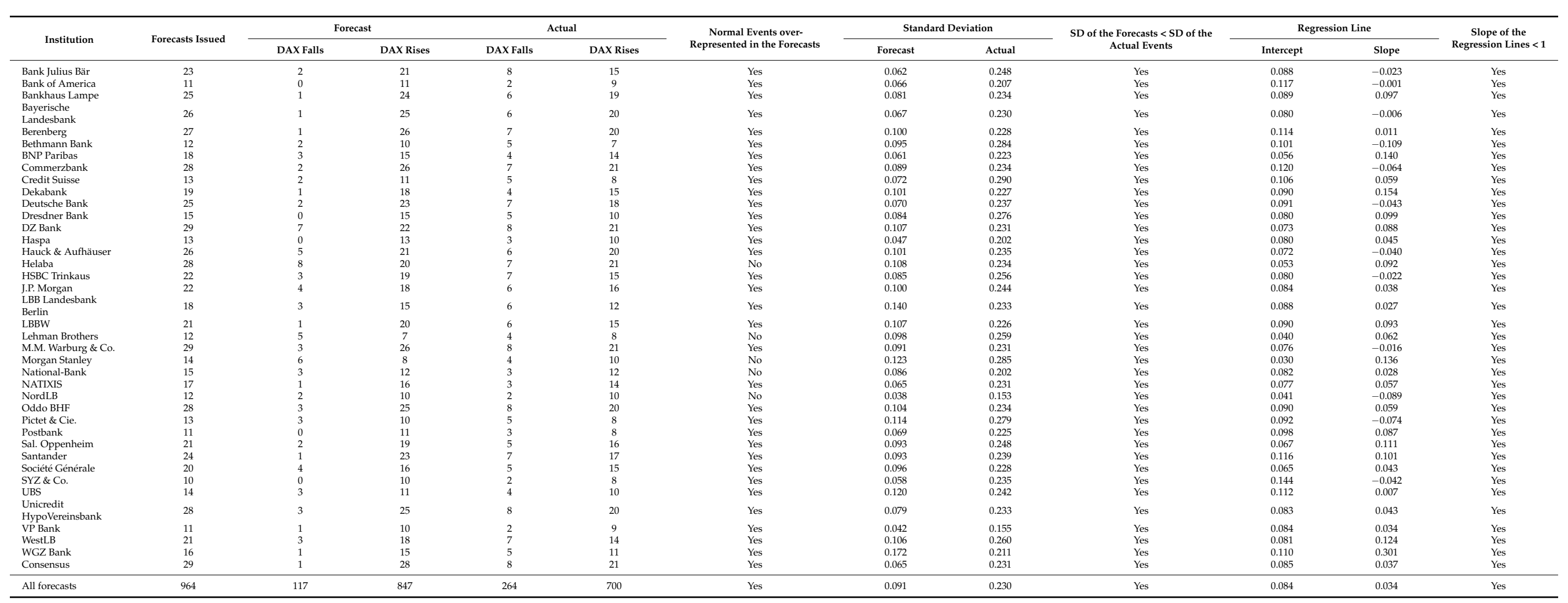

DAX = German Stock Market Index; SD = standard deviation. 


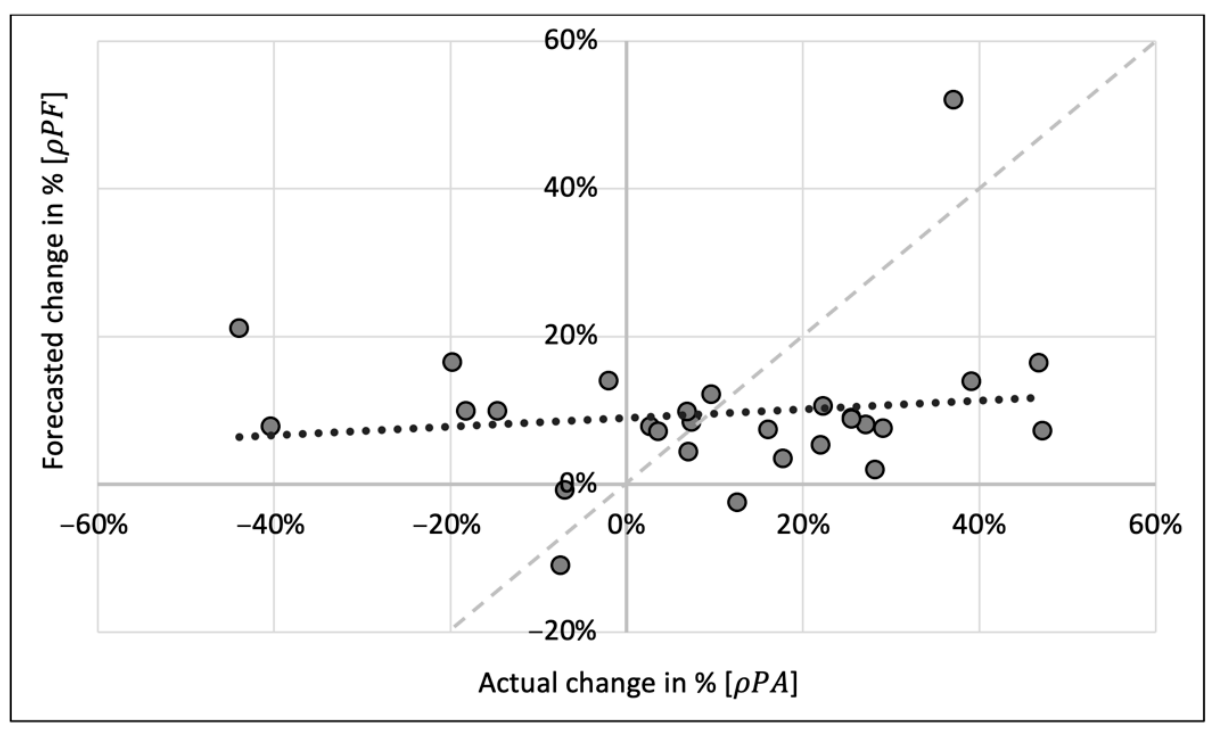

Figure 4. Prediction-realization diagram of the DAX forecasts of Oddo BHF. Dotted line = regression line; dashed line $=$ perfect forecasts according to the prediction-realization diagram .

In addition, it can be seen that the dispersion of the actual events (scattering along the $\rho P A$ axis) is greater than the dispersion of the forecasts (scattering along the $\rho P F$ axis). The standard deviation of the actual events is $23.39 \%$. The standard deviation of the forecasts, however, is only $10.41 \%$ (Table 3). The slope of 0.059 in the dotted regression line in the prediction-realization diagram is thus nowhere near the threshold value 1 (dashed diagonal line) (Table 3). The variability of the actual events is dramatically underestimated.

Table 3 depicts the main results of the DAX forecasts from the Handelsblatt newspaper. All of the forecasters who have taken part in the forecasting surveys of the Handelsblatt for at least ten years are analyzed individually. All of the forecasters who issue less than 10 forecasts in the period from 1992 to 2020 are not analyzed individually but are taken into account as part of the overall analysis of all forecasts and within the framework of the consensus forecasts (final lines in Table 3).

The seventh column of Table 3 indicates whether fewer falls in the DAX are forecasted than actually occur. As the DAX is a performance index and exhibits a rising trend over the long term, all falls in the index are interpreted as 'unusual events'. According to Ogburn (1934), conservative forecasting leads to 'normal events' (here: an increase in the DAX) being over-represented in the forecasts, while 'unusual events' (here: a decrease in the DAX) are under-represented in the forecasts. This is the case in 33 of the 38 forecasters who are analyzed individually here: a proportion of $86.8 \%$. Unusual events are also under-represented in the consensus forecasts and when the total number of the forecasts is considered as a whole. The detailed data is given in Table 3, where one can see how often a falling DAX was forecast, and how often the DAX really falls. One can also note how often an upward trend was forecast for the DAX, and how often the DAX really rises (Table 3).

The picture is clearer in the case of the standard deviations. According to Ogburn (1934), conservative forecasting leads to standard deviations of the forecasts which are lower than the standard deviations of the actual events. The tenth column of Table 3 considers whether this applies to the DAX forecasts and reveals that this is the case in all 38 of the 38 forecasters analyzed. Also, with regard to the consensus forecasts and when all 964 forecasts are considered, the standard deviation of the forecasts lags behind the standard deviation of the actual events (Table 3).

Ogburn (1934) states that conservative forecasting leads to an underestimation of the variability of reality. In the prediction-realization diagram, this should lead to a slope in the regression lines which is lower than one. The last column of Table 3 illustrates this aspect. It can be seen that in 38 out of 38 cases, the slope in the regression lines is lower than one. 
The fact that the slopes are usually clearly below the threshold value of one is also revealed in the detailed data on the intercepts and the slopes in the regression lines (Table 3).

The German quality newspaper the Frankfurter Allgemeine Zeitung (FAZ) only started a regular survey of forecasts in 2002. As a result, the share price falls in the years 2000 and 2001 no longer have an effect. It is interesting to see whether this leads to significantly different results in the forecasts. In addition, the Frankfurter Allgemeine Zeitung not only surveys annual forecasts, but also six-month forecasts. It is quite possible that the characteristics of the forecasts with differing forecast horizons vary. Once again, all of the forecasters who have taken part in the forecasting surveys of the FAZ at least ten times are analyzed individually (Table 4).

The results are in fact somewhat less clear than those for the DAX forecasts from the Handelsblatt. In 24 out of 33 cases (72.7\%), normal events (increase in the DAX) are over-represented in the forecasts (seventh column in Table 4). Unusual events are also under-represented in the consensus forecasts and when all 282 six-month and all 402 twelvemonth forecasts are considered as a whole.

The result of the standard deviations is quite clear: In 31 out of 33 cases (93.9\%), the forecasts lag behind the actual events (tenth column in Table 4). This finding also applies to the consensus forecasts as well as when all 282 six-month and all 402 twelve-month forecasts are considered as a whole.

The fact that the forecasters persistently underestimate the variability of reality is revealed most clearly in the slope of the regression lines in the prediction-realization diagram (last column in Table 4). In 33 out of 33 cases, the slope is below one. This result also applies to the consensus forecasts as well as when all 282 six-month and all 402 twelve-month forecasts are considered as a whole.

The forecasts of the Dow Jones Industrial Index yield only slightly different results. Once again, all of the forecasters who have taken part in the forecasting survey at least ten times are analyzed individually (Table 5).

The Dow Jones Industrial Index is a price index, but it exhibits a long-term rising trend, nevertheless. To this extent, one can also presume here that a rise in the index can be considered a normal event, and that a fall in the index represents an unusual event. In ten out of 16 cases $(62.5 \%)$, normal events (increase of the Dow Jones Industrial Index) are over-represented in the forecasts (seventh column in Table 5). Unusual events are also under-represented in the consensus forecasts and when all 203 six-month and all 259 twelve-month forecasts are considered as a whole.

The result for the standard deviations is more marked. In 14 out of 16 cases (87.5\%), the fluctuations in the forecasts lag behind those of the actual events (tenth column in Table 5). This finding also applies to the consensus forecasts as well as when all 203 six-month and all 259 twelve-month forecasts are considered as a whole.

The fact that the forecasters persistently underestimate the variability of reality is revealed most clearly in the slope of the regression lines in the prediction-realization diagram (last column in Table 5). In 16 out of 16 cases, the slope is below one. This is also the same for the consensus forecasts as well as when all 203 six-month and all 259 twelve-month forecasts are viewed as a whole.

The picture drawn by the forecasts of the Euro Stoxx 50 is even more distinct (Table 6). Here again, all of the forecasters who have taken part in the forecasting survey at least ten times are analyzed individually. All of the other forecasts form part of the consensus forecasts and are also evaluated as part of the total number of forecasts. 
Table 4. The main results of the DAX forecasts from 2002 to 2020 from the FAZ.

\begin{tabular}{|c|c|c|c|c|c|c|c|c|c|c|c|c|}
\hline \multirow{2}{*}{ Institution } & \multirow{2}{*}{ Forecasts Issued } & \multicolumn{2}{|c|}{ Forecast } & \multicolumn{2}{|c|}{ Actual } & \multirow{2}{*}{$\begin{array}{l}\text { Normal Events over- } \\
\text { Represented in the Forecasts }\end{array}$} & \multicolumn{2}{|c|}{ Standard Deviation } & \multirow{2}{*}{$\begin{array}{l}\text { SD of the Forecasts }<\text { SD of the } \\
\text { Actual Events }\end{array}$} & \multicolumn{2}{|c|}{ Regression Line } & \multirow{2}{*}{$\begin{array}{c}\text { Slope of the } \\
\text { Regression Lines }<1\end{array}$} \\
\hline & & DAX Falls & DAX Rises & DAX Falls & DAX Rises & & Forecast & Actual & & Intercept & Slope & \\
\hline \multicolumn{13}{|c|}{ Forecast horizon 6 months } \\
\hline Bayern LB & 10 & 5 & 5 & 3 & 7 & No & 0.047 & 0.094 & Yes & 0.028 & -0.286 & Yes \\
\hline Deka Bank & 16 & 3 & 13 & 5 & ${ }_{11}^{11}$ & Yes & 0.061 & 0.096 & Yes & 0.040 & -0.002 & Yes \\
\hline $\begin{array}{l}\text { DZ Bank } \\
\text { Helaba }\end{array}$ & $\begin{array}{l}16 \\
14\end{array}$ & $\begin{array}{l}6 \\
6\end{array}$ & ${ }_{8}^{10}$ & $\begin{array}{l}5 \\
5\end{array}$ & 11 & No & $\begin{array}{l}0.065 \\
0.055\end{array}$ & $\begin{array}{l}0.096 \\
0102\end{array}$ & $\begin{array}{l}\text { Yes } \\
\text { Yes }\end{array}$ & $\begin{array}{l}0.009 \\
0.025\end{array}$ & ${ }_{-0.0325}^{0.025}$ & $\begin{array}{l}\text { Yes } \\
\text { Yes }\end{array}$ \\
\hline $\begin{array}{l}\text { Helaba } \\
\text { HSH Nordbank }\end{array}$ & $\begin{array}{l}14 \\
10\end{array}$ & $\begin{array}{l}6 \\
7\end{array}$ & $\begin{array}{l}8 \\
3 \\
3\end{array}$ & $\begin{array}{r}5 \\
4\end{array}$ & $\begin{array}{l}9 \\
6\end{array}$ & $\begin{array}{l}\text { No } \\
\text { No }\end{array}$ & $\begin{array}{l}0.075 \\
0.095\end{array}$ & $\begin{array}{l}0.102 \\
0.098\end{array}$ & $\begin{array}{l}\text { Yes } \\
\text { YYs }\end{array}$ & $\begin{array}{c}0.025 \\
-0.030\end{array}$ & $\begin{array}{l}-0.375 \\
-0.039\end{array}$ & $\begin{array}{l}\text { Yes } \\
\text { YYs }\end{array}$ \\
\hline $\begin{array}{l}\text { HSH Nordabank } \\
\text { HVB-Unicredit Bank }\end{array}$ & 16 & 4 & $\begin{array}{l}3 \\
12\end{array}$ & $\begin{array}{l}4 \\
6 \\
6\end{array}$ & $\begin{array}{l}6 \\
10\end{array}$ & $\begin{array}{l}\text { No } \\
\text { Yes }\end{array}$ & $\begin{array}{l}0.005 \\
0.063\end{array}$ & $\begin{array}{l}0.1048 \\
0.104\end{array}$ & $\begin{array}{l}\text { YYes } \\
\text { Yes }\end{array}$ & $\begin{array}{l}-0.035 \\
0.035\end{array}$ & ${ }_{-0.035}^{-0.039}$ & $\begin{array}{l}\text { YYes } \\
\text { Yes }\end{array}$ \\
\hline LBBW & 17 & ${ }_{3}^{7}$ & 14 & $\frac{0}{6}$ & 11 & Yes & 0.048 & 0.102 & Yes & 0.019 & 0.090 & Yes \\
\hline M.M. Warburg & 17 & 3 & 14 & 6 & 11 & Yes & 0.122 & 0.102 & No & 0.030 & -0.039 & Yes \\
\hline $\begin{array}{l}\text { Oddo BHF } \\
\text { Potbank }\end{array}$ & 10 & & 9 & 4 & 6 & Yes & 0.041 & 0.121 & Yes & 0.049 & -0.058 & Yes \\
\hline $\begin{array}{l}\text { Postbank } \\
\text { Santander Asset }\end{array}$ & 13 & 6 & 7 & 4 & 9 & No & 0.071 & 0.104 & Yes & 0.008 & -0.087 & Yes \\
\hline $\begin{array}{l}\text { Santander Asset } \\
\text { Mgmt. }\end{array}$ & 13 & 1 & 12 & 3 & 10 & Yes & 0.029 & 0.099 & Yes & 0.033 & 0.073 & Yes \\
\hline Société Générale & 10 & 6 & 4 & 3 & 7 & No & 0.087 & 0.072 & No & -0.023 & -0.431 & Yes \\
\hline Consensus & 17 & 2 & $\begin{array}{l}7 \\
15 \\
\end{array}$ & 6 & 11 & Yes & 0.028 & 0.102 & Yes & 0.024 & -0.077 & $\begin{array}{l}\text { Yes } \\
\text { Yes }\end{array}$ \\
\hline All forecasts & 282 & 83 & 199 & 103 & 179 & Yes & 0.072 & 0.095 & Yes & 0.024 & -0.076 & Yes \\
\hline \multicolumn{13}{|c|}{ Forecast horizon 12 months } \\
\hline Allianz SE & 11 & 0 & 11 & 2 & 9 & Yes & 0.044 & 0.155 & Yes & 0.072 & 0.018 & Yes \\
\hline Bayern LB & 11 & 0 & 11 & 2 & 9 & Yes & 0.036 & 0.159 & Yes & 0.069 & 0.011 & Yes \\
\hline $\begin{array}{l}\text { BNP Paribas } \\
\text { Commerzbank }\end{array}$ & $\begin{array}{l}12 \\
18\end{array}$ & $\begin{array}{l}1 \\
0\end{array}$ & ${ }_{18}^{11}$ & 3 & ${ }_{14}^{9}$ & $\begin{array}{l}\text { Yes } \\
\text { Yes }\end{array}$ & $\begin{array}{l}0.055 \\
0.081\end{array}$ & $\begin{array}{l}0.210 \\
0.233\end{array}$ & $\begin{array}{l}\text { Yes } \\
\text { Yes }\end{array}$ & $\begin{array}{l}0.066 \\
0.19\end{array}$ & $\begin{array}{l}0.110 \\
0.032\end{array}$ & $\begin{array}{l}\text { Yes } \\
\text { Yes }\end{array}$ \\
\hline $\begin{array}{l}\text { Commerzbank } \\
\text { Deka Bank }\end{array}$ & $\begin{array}{l}18 \\
18\end{array}$ & $\begin{array}{l}0 \\
1\end{array}$ & $\begin{array}{l}18 \\
17\end{array}$ & ${ }_{3}^{4}$ & $\begin{array}{l}14 \\
15\end{array}$ & $\begin{array}{l}\text { Yes } \\
\text { Yes }\end{array}$ & $\begin{array}{l}0.0 .101 \\
0.104\end{array}$ & $\begin{array}{l}0.233 \\
0.195\end{array}$ & $\begin{array}{l}\text { Yes } \\
\text { Yes }\end{array}$ & $\begin{array}{l}.0 .199 \\
0.082\end{array}$ & $\begin{array}{l}0.032 \\
0.200\end{array}$ & $\begin{array}{l}\text { YYes } \\
\text { Yes }\end{array}$ \\
\hline Deutsche Bank & 10 & 0 & 10 & 2 & 8 & Yes & 0.047 & 0.212 & Yes & 0.104 & $\begin{array}{l}-0.017 \\
-0.017\end{array}$ & Yes \\
\hline DWS & 13 & 0 & 13 & 3 & 10 & Yes & 0.027 & 0.202 & Yes & 0.076 & 0.038 & Yes \\
\hline DZ Bank & 18 & 2 & 16 & 4 & 14 & Yes & 0.066 & 0.222 & Yes & 0.072 & 0.063 & Yes \\
\hline $\begin{array}{l}\text { Helaba } \\
H \text { SPC Trink s }\end{array}$ & 15 & 6 & 9 & 3 & 12 & No & 0.121 & 0.196 & Yes & 0.025 & 0.249 & Yes \\
\hline $\begin{array}{l}\text { HSBC Irinkaus \& } \\
\text { Burkhardt }\end{array}$ & 13 & 2 & 11 & 3 & 10 & Yes & 0.066 & 0.262 & Yes & 0.065 & -0.102 & Yes \\
\hline HSH Nordbank & 11 & 2 & 9 & 3 & 8 & Yes & 0.080 & 0.213 & Yes & 0.055 & 0.192 & Yes \\
\hline HVB-Unicredit Bank & 18 & 1 & 17 & 4 & 14 & Yes & 0.078 & 0.228 & Yes & 0.077 & 0.077 & Yes \\
\hline J.P. Morgan & 12 & 1 & 11 & 3 & 9 & Yes & 0.064 & 0.233 & Yes & 0.095 & 0.140 & Yes \\
\hline $\begin{array}{l}\text { LBBW } \\
\text { MM Warburr }\end{array}$ & $\begin{array}{l}19 \\
19\end{array}$ & 0 & $\begin{array}{l}19 \\
18\end{array}$ & ${ }_{4}^{4}$ & $\begin{array}{l}15 \\
15\end{array}$ & $\begin{array}{l}\text { Yes } \\
\text { Yes }\end{array}$ & $\begin{array}{l}0.097 \\
0.077\end{array}$ & 0.227 & $\begin{array}{l}\text { Yes } \\
\text { Yys }\end{array}$ & $\begin{array}{l}0.091 \\
0.78\end{array}$ & $\begin{array}{c}0.093 \\
-0.018\end{array}$ & $\begin{array}{l}\text { Yes } \\
\text { Yes }\end{array}$ \\
\hline $\begin{array}{l}\text { M.M. Warburg } \\
\text { Oddo BHF }\end{array}$ & $\begin{array}{l}199 \\
17\end{array}$ & $\begin{array}{l}1 \\
1\end{array}$ & $\begin{array}{l}18 \\
16\end{array}$ & $\begin{array}{l}4 \\
4\end{array}$ & $\begin{array}{l}15 \\
13\end{array}$ & $\begin{array}{l}\text { Yes } \\
\text { Yes }\end{array}$ & $\begin{array}{l}0.097 \\
0.045\end{array}$ & $\begin{array}{l}0.227 \\
0.225\end{array}$ & $\begin{array}{l}\text { Yes } \\
\text { Yes }\end{array}$ & $\begin{array}{l}0.078 \\
0.093\end{array}$ & $\begin{array}{l}-0.018 \\
-0.092\end{array}$ & $\begin{array}{l}\text { YYes } \\
\text { Yes }\end{array}$ \\
\hline Postbank & 14 & 0 & 14 & ${ }_{3}^{4}$ & 11 & $\begin{array}{l}\text { Tes } \\
\text { Yes }\end{array}$ & $\begin{array}{l}.0 .075 \\
0.070\end{array}$ & 0.208 & $\begin{array}{l}\text { Tes } \\
\text { Yes }\end{array}$ & $\begin{array}{l}0.096 \\
0.996\end{array}$ & $\begin{array}{l}-0.048 \\
0.048\end{array}$ & $\begin{array}{l}\text { Yes } \\
\text { Yes }\end{array}$ \\
\hline $\begin{array}{l}\text { Santander Asset } \\
\text { Mgmt. }\end{array}$ & 16 & 0 & 16 & 3 & 13 & Yes & 0.052 & 0.195 & Yes & 0.107 & 0.048 & Yes \\
\hline $\begin{array}{l}\text { Mgmté } \\
\text { Sociéténérale }\end{array}$ & 11 & 4 & 7 & 2 & 9 & & 0.088 & 0.155 & Yes & 0.067 & -0.347 & Yes \\
\hline UBS & 10 & 1 & 9 & 1 & 9 & No & 0.118 & 0.151 & Yes & 0.136 & 0.027 & Yes \\
\hline WestLB & 11 & 2 & 9 & 3 & 8 & $\begin{array}{l}\text { Yes } \\
\text { Yes }\end{array}$ & 0.128 & 0.282 & Yes & 0.075 & 0.204 & Yes \\
\hline Consensus & 19 & 0 & 19 & 4 & 15 & Yes & 0.061 & 0.227 & Yes & 0.087 & 0.064 & Yes \\
\hline All forecasts & 402 & 31 & 371 & 88 & 314 & Yes & 0.083 & 0.215 & Yes & 0.085 & 0.054 & Yes \\
\hline
\end{tabular}

DAX = German Stock Market Index; FAZ = Frankfurter Allgemeine Zeitung; SD = standard deviation. 
Table 5. Main results of the forecasts of the DJI from 2004 to 2020 from the FAZ.

\begin{tabular}{|c|c|c|c|c|c|c|c|c|c|c|c|c|}
\hline \multirow{2}{*}{ Institution } & \multirow{2}{*}{ Forecasts Issued } & \multicolumn{2}{|c|}{ Forecast } & \multicolumn{2}{|c|}{ Actual } & \multirow{2}{*}{$\begin{array}{l}\text { Normal Events over-Represented } \\
\text { in the Forecasts }\end{array}$} & \multicolumn{2}{|c|}{ Standard Deviation } & \multirow{2}{*}{$\begin{array}{l}\text { SD of the Forecasts }<\text { SD of the } \\
\text { Actual Events }\end{array}$} & \multicolumn{2}{|c|}{ Regression Line } & \multirow{2}{*}{$\begin{array}{c}\text { Slope of the } \\
\text { Regression Lines < }\end{array}$} \\
\hline & & DJI Falls & DJI Rises & DJI Falls & DJI Rises & & Forecast & Actual & & Intercept & Slope & \\
\hline \multicolumn{13}{|c|}{ Forecast horizon 6 months } \\
\hline Deka Bank & 15 & 5 & 10 & 8 & 7 & Yes & 0.070 & 0.066 & No & 0.018 & 0.171 & Yes \\
\hline $\begin{array}{l}\text { Helaba } \\
\text { LBBW }\end{array}$ & $\begin{array}{l}14 \\
16\end{array}$ & $\begin{array}{l}6 \\
7\end{array}$ & $\begin{array}{c}8 \\
9\end{array}$ & $\begin{array}{l}6 \\
8\end{array}$ & $\begin{array}{l}8 \\
8\end{array}$ & $\begin{array}{l}\text { No } \\
\text { Yes }\end{array}$ & $\begin{array}{l}0.081 \\
0.052\end{array}$ & $\begin{array}{l}0.077 \\
0.073\end{array}$ & $\begin{array}{l}\text { No } \\
\text { Yes }\end{array}$ & 0.019 & $\begin{array}{l}-0.406 \\
0.016\end{array}$ & $\begin{array}{l}\text { Yes } \\
\text { Yes }\end{array}$ \\
\hline M.M. Warburg & $\begin{array}{l}16 \\
15\end{array}$ & 3 & 12 & 7 & 8 & $\begin{array}{l}\text { Yes } \\
\text { Yes }\end{array}$ & $\begin{array}{l}0.061 \\
0.061\end{array}$ & 0.075 & $\begin{array}{l}\text { Yes } \\
\text { Yes }\end{array}$ & 0.034 & $\begin{array}{l}0.233 \\
0.233\end{array}$ & \\
\hline $\begin{array}{l}\text { Postbank } \\
\text { Pong }\end{array}$ & 12 & 6 & 6 & 5 & 7 & No & 0.053 & 0.079 & $\begin{array}{l}\text { res } \\
\text { Yes }\end{array}$ & $\begin{array}{l}0.003 \\
0.003\end{array}$ & 0.035 & $\begin{array}{l}\text { Tes } \\
\text { Yes }\end{array}$ \\
\hline $\begin{array}{l}\text { Santander Asset } \\
\text { Momt }\end{array}$ & 13 & 1 & 12 & 6 & 7 & Yes & 0.019 & 0.081 & Yes & 0.026 & -0.095 & Yes \\
\hline Consensus & 16 & 4 & 12 & 8 & 8 & Yes & 0.019 & 0.073 & Yes & 0.014 & 0.036 & Yes \\
\hline All forecasts & 203 & 67 & 136 & 106 & 97 & Yes & 0.061 & 0.070 & Yes & 0.014 & 0.040 & Yes \\
\hline \multicolumn{13}{|c|}{ Forecast horizon 12 months } \\
\hline BNP Paribas & 10 & 0 & 10 & 3 & 7 & Yes & 0.040 & 0.183 & Yes & 0.072 & -0.059 & Yes \\
\hline Commerzbank & 10 & 0 & 10 & 3 & 7 & Yes & 0.052 & 0.169 & Yes & 0.081 & 0.120 & Yes \\
\hline Deka Bank & 16 & 6 & 10 & 4 & 12 & No & 0.099 & 0.137 & Yes & 0.051 & 0.002 & Yes \\
\hline $\begin{array}{l}\text { Helaba } \\
\text { HSH }\end{array}$ & ${ }_{11}^{15}$ & $\begin{array}{l}7 \\
5\end{array}$ & $\begin{array}{l}8 \\
6 \\
6\end{array}$ & $\begin{array}{l}3 \\
3 \\
3\end{array}$ & ${ }_{8}^{12}$ & No & 0.107 & $\begin{array}{l}0.149 \\
0.163\end{array}$ & $\begin{array}{l}\text { Yes } \\
\text { Yes }\end{array}$ & 0.008 & $\begin{array}{l}0.193 \\
-0.032\end{array}$ & $\begin{array}{l}\text { Yes } \\
\text { Yes }\end{array}$ \\
\hline $\begin{array}{l}\text { HSH Nordbank } \\
\text { LBBW }\end{array}$ & ${ }_{17}^{11}$ & $\begin{array}{l}5 \\
4\end{array}$ & $\begin{array}{c}6 \\
13 \\
\end{array}$ & $\begin{array}{l}3 \\
4\end{array}$ & $\begin{array}{c}8 \\
13\end{array}$ & $\begin{array}{l}\text { No } \\
\text { No }\end{array}$ & 0.058 & $\begin{array}{l}0.163 \\
0.142\end{array}$ & $\begin{array}{l}\text { Yyes } \\
\text { Yes }\end{array}$ & $\begin{array}{l}0.022 \\
0.053\end{array}$ & $\begin{array}{l}-0.0325 \\
-0.04\end{array}$ & $\begin{array}{l}\text { Yes } \\
\text { Yes }\end{array}$ \\
\hline M.M. Warburg & ${ }_{17}^{1 /}$ & 1 & $\begin{array}{l}13 \\
16\end{array}$ & $\begin{array}{l}4 \\
4\end{array}$ & 13 & $\begin{array}{l}\text { No } \\
\text { Yes }\end{array}$ & $\begin{array}{l}0.071 \\
0.071\end{array}$ & $\begin{array}{l}0.142 \\
0.142\end{array}$ & $\begin{array}{l}\text { Yes } \\
\text { Yes }\end{array}$ & $\begin{array}{l}0.063 \\
0.063\end{array}$ & $\begin{array}{l}-0.042 \\
-0.107\end{array}$ & $\begin{array}{l}\text { Yes } \\
\text { Yes }\end{array}$ \\
\hline & 15 & 0 & 15 & 3 & 12 & Yes & 0.022 & 0.147 & Yes & 0.058 & 0.054 & Yes \\
\hline $\begin{array}{l}\text { Postbank } \\
\text {. }\end{array}$ & 13 & 0 & 13 & 3 & 10 & Yes & 0.063 & 0.160 & Yes & 0.084 & 0.012 & Yes \\
\hline $\begin{array}{l}\text { Santander Asset } \\
\text { Mgmt. }\end{array}$ & 16 & 0 & 16 & 4 & 12 & Yes & 0.051 & 0.146 & Yes & 0.070 & 0.093 & Yes \\
\hline Consensus & 17 & 0 & 17 & 4 & 13 & Yes & 0.033 & 0.142 & Yes & 0.055 & 0.006 & Yes \\
\hline All forecasts & 259 & 33 & 226 & 65 & 194 & Yes & 0.066 & 0.140 & Yes & 0.057 & 0.029 & Yes \\
\hline
\end{tabular}

DJI = Dow Jones Industrial Index; FAZ = Frankfurter Allgemeine Zeitung; SD = standard deviation. 
Table 6. The main results for the Euro Stoxx 50 forecasts from 2002 to 2020 from the FAZ.

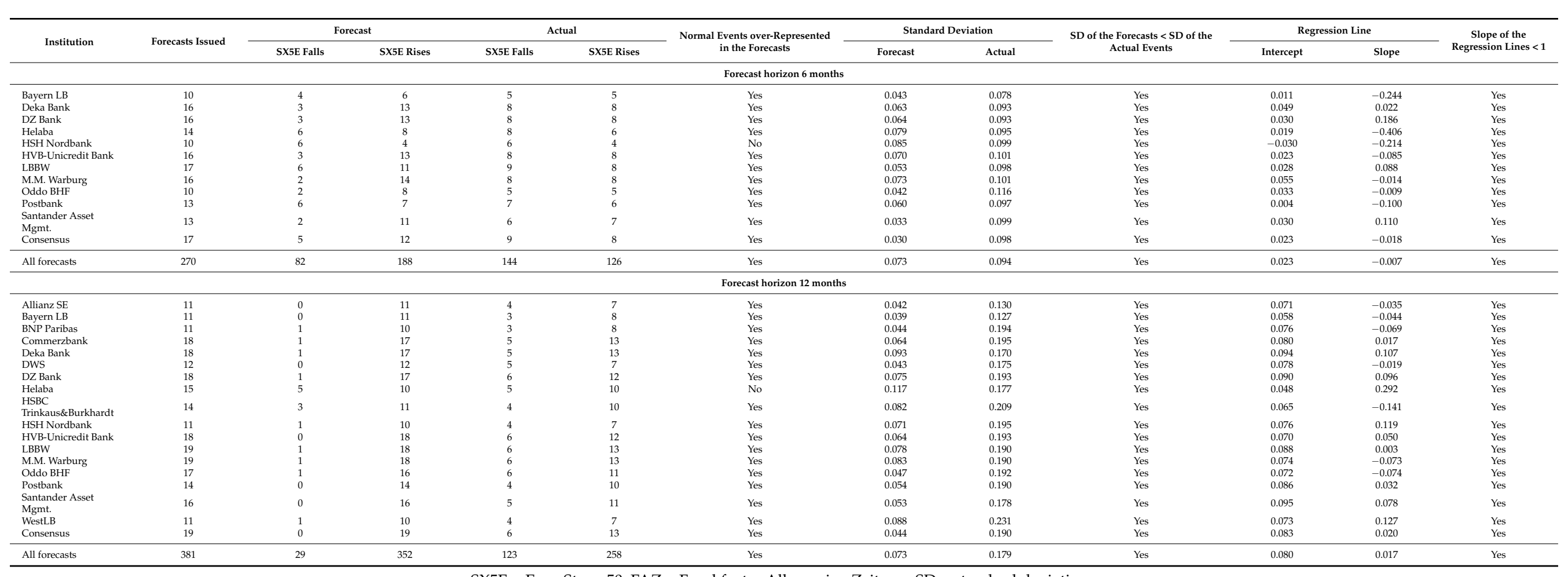

SX5E = Euro Stoxx 50; FAZ = Frankfurter Allgemeine Zeitung; SD = standard deviation. 
Conservatism among forecasters can lead to them forecasting unusual events too rarely. The Euro Stoxx 50 is a price index, but in spite of this it exhibits a long-term upward trend. To this extent, one can also presume here that a rise in the index can be considered a normal event, and that a fall in the index represents an unusual event. In the predictions of 24 of the 26 forecasters analyzed individually (92.3\%), unusual events are under-represented (seventh column in Table 6). The consensus forecasts and the overall total of all 270 six-month forecasts and all 381 twelve-month forecasts also show that unusual events are forecast more seldom than they occur in reality.

The standard deviations provide a very clear picture. The standard deviations of the forecasts lag behind the standard deviations of the actual results in 26 out of 26 cases (tenth column in Table 6). This also applies to the consensus forecasts and the overall total of 270 forecasts with a forecast horizon of six months and all 381 forecasts with a forecast horizon of twelve months.

Finally, it can be seen that the slope in the regression lines in the prediction-realization diagrams is significantly below one in 26 out of 26 cases. The forecasters are thus obviously underestimating the variability of reality (last column in Table 6). These findings are also confirmed when the consensus forecasts and the overall total number of forecasts are considered.

Without exception, it can be observed that the forecasters underestimate the variability of reality. This fact can be clearly seen when looking at the kernel density plots of the forecast relative changes in share prices and the actual relative changes in share prices (Figure 5). The spread of the forecasts is much smaller than the spread of the actual events.

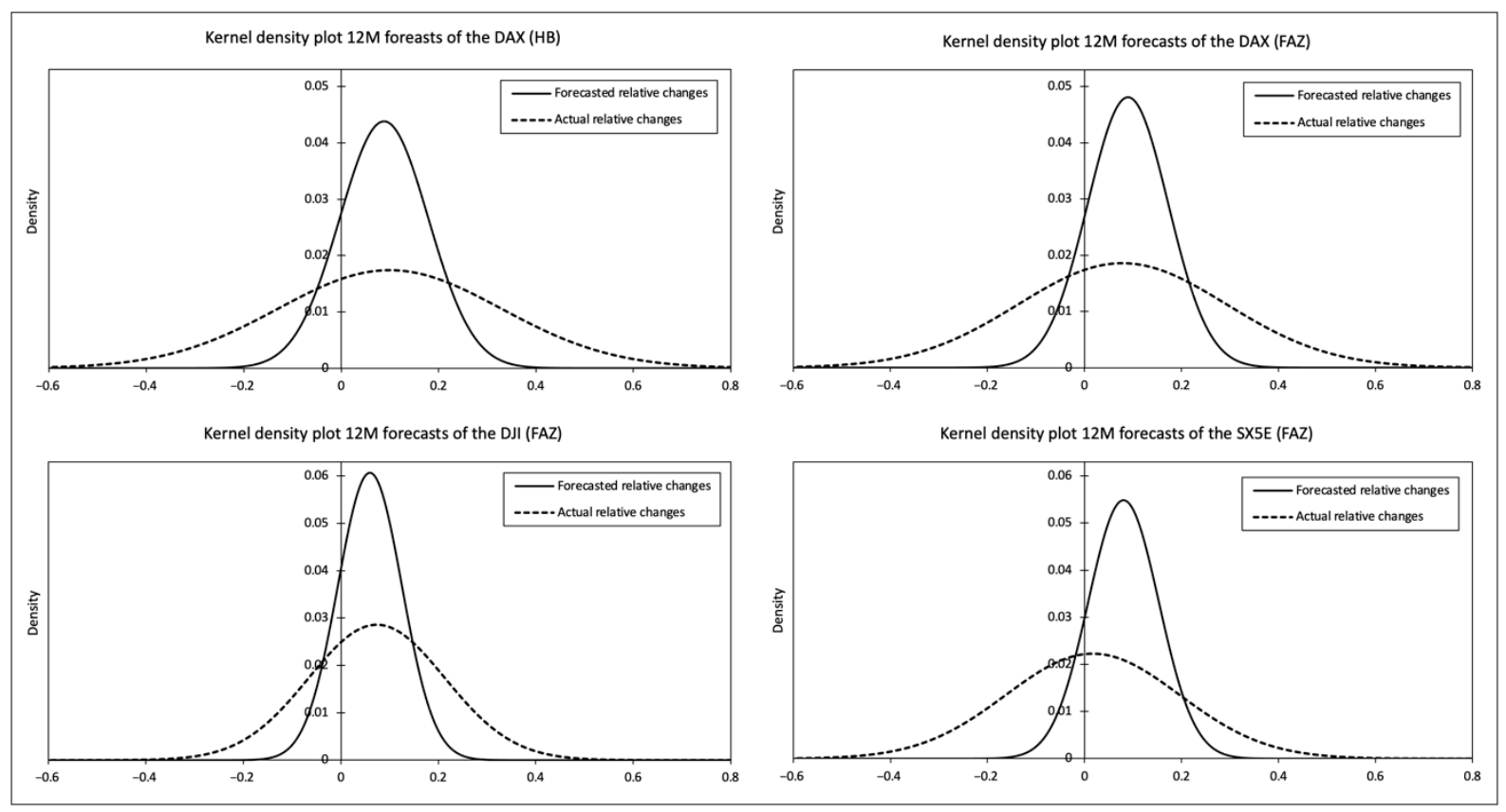

Figure 5. Kernel density plots of the forecast and actual changes of stock-market indices. HB = Handelsblatt; FAZ = Frankfurter Allgemeine Zeitung; DAX = German Stock Market Index; DJI = Dow Jones Industrial Index; SX5E = Euro Stoxx 50; $12 \mathrm{M}=$ Forecast horizon of 12 months.

This can be also seen in the fact that the slope in the regression lines in the predictionrealization diagram always remains below the threshold value of one. This leads us to the assessment that this aspect in particular deserves special attention. The unbiasedness test takes the slope of the regression line in the prediction-realization diagram into account as an essential element. Forecasts are viewed as unbiased when the slope in the regression line does not diverge significantly from one, the intercept of the regression line does not deviate significantly from zero, and the residuals are randomly distributed. The decisive 
advantage of this approach lies in the opportunity to go beyond purely descriptive statistics and to examine the statistical significance of the results.

In all seven cases, it can be seen that given an error probability of $\leq 1 \%$ either the slope of the regression line in the prediction-realization diagram is $\neq 1$ and/or the intercept is $\neq 0$. In addition, the residuals are obviously not randomly distributed in six of the seven cases. The forecasts are clearly not unbiased (Table 7).

Table 7. Unbiasedness test.

\begin{tabular}{|c|c|c|c|c|c|c|c|}
\hline $\begin{array}{c}\text { Stock Market } \\
\text { Index }\end{array}$ & Source & $\begin{array}{l}\text { Forecast } \\
\text { Horizon }\end{array}$ & $\begin{array}{l}\text { Number of } \\
\text { Observations }\end{array}$ & Slope & Intercept & $\begin{array}{c}\text { F Test } \\
p \text {-Value }\end{array}$ & $\begin{array}{c}\text { Wooldridge Test } \\
p \text {-Value }\end{array}$ \\
\hline DAX & $\mathrm{HB}$ & $12 \mathrm{M}$ & 964 & 0.034 & 0.084 & 0.000 & 0.000 \\
\hline DAX & FAZ & $6 \mathrm{M}$ & 282 & -0.075 & 0.024 & 0.000 & 0.000 \\
\hline DAX & FAZ & $12 \mathrm{M}$ & 402 & 0.054 & 0.085 & 0.000 & 0.006 \\
\hline DJI & FAZ & $6 \mathrm{M}$ & 203 & 0.040 & 0.014 & 0.010 & 0.098 \\
\hline DJI & FAZ & $12 \mathrm{M}$ & 259 & 0.029 & 0.057 & 0.000 & 0.623 \\
\hline SX5E & FAZ & $6 \mathrm{M}$ & 270 & -0.007 & 0.023 & 0.000 & 0.091 \\
\hline SX5E & FAZ & $12 \mathrm{M}$ & 381 & 0.017 & 0.080 & 0.000 & 0.042 \\
\hline
\end{tabular}

DAX = German Stock Market Index; DJI = Dow Jones Industrial Index; SX5E = Euro Stoxx 50; HB = Handelsblatt; FAZ = Frankfurter Allgemeine Zeitung; $12 \mathrm{M}=12$ months; $6 \mathrm{M}=6$ months.

Finally, with the aid of the Diebold-Mariano test we examine whether the quality of the forecasts is significantly superior-from a statistical perspective-to that of naïve forecasts (Table 8). The result is that the forecasts of the Euro Stoxx 50 are significantly poorer than the corresponding naïve forecasts, and the quality of the forecasts for the DAX and the Dow Jones Industrial Index does not go significantly beyond that of naïve forecasts.

Table 8. Comparison of the forecasts with the naïve forecast.

\begin{tabular}{ccccc}
\hline \multirow{2}{*}{ Stock Market Index } & Source & Forecast Horizon & \multicolumn{2}{c}{ Diebold-Mariano Test } \\
\cline { 4 - 5 } & & & Result & $p$-Value \\
\hline DAX & HB & $12 \mathrm{M}$ & $\mathrm{o}$ & 0.8143 \\
DAX & FAZ & $6 \mathrm{M}$ & $\mathrm{o}$ & 0.1221 \\
DAX & FAZ & $12 \mathrm{M}$ & $\mathrm{o}$ & 0.7429 \\
DJI & FAZ & $6 \mathrm{M}$ & $\mathrm{o}$ & 0.7053 \\
DJI & FAZ & $12 \mathrm{M}$ & $\mathrm{o}$ & 0.3491 \\
SX5E & FAZ & $6 \mathrm{M}$ & - & 0.0000 \\
SX5E & FAZ & $12 \mathrm{M}$ & - & 0.0540 \\
\hline
\end{tabular}

$\mathrm{o}=$ no significant result, $-=$ significantly poorer than the naïve forecasts, $+=$ significantly better than the naïve forecast, DAX = German Stock Market Index; DJI = Dow Jones Industrial Index; SX5E = Euro Stoxx 50; $\mathrm{HB}=$ Handelsblatt; FAZ = Frankfurter Allgemeine Zeitung; $12 \mathrm{M}=12$ months; $6 \mathrm{M}=6$ months.

In Table 9 the results of the hypothesis testing are summarized. In Hypotheses 1-3, the result which was determined for "all forecasts" in a forecasting area is used. In the case of the DAX forecasts from the Handelsblatt survey, for example, that is the 964 forecasts which are noted in the final line of Table 3. For Hypothesis 4, the results of the unbiasedness test (Table 7) are taken into account, and for Hypothesis 5 the results of the Diebold-Mariano test (Table 8).

In the case of Hypothesis 1 there is a uniform pattern for all areas of forecasting and all forecast horizons. Normal events (index rises) are over-represented in the forecasts. Unusual events (index falls) are under-represented in the forecasts. Null Hypothesis 1 has to be rejected in all seven cases. 
Table 9. The results of hypothesis testing.

\begin{tabular}{cccccccc}
\hline $\begin{array}{c}\text { Stock Market } \\
\text { Index }\end{array}$ & Source & $\begin{array}{c}\text { Forecast } \\
\text { Horizon }\end{array}$ & Hypothesis 1 & Hypothesis 2 & Hypothesis 3 & Hypothesis 4 & Hypothesis 5 \\
\hline DAX & HB & $12 \mathrm{M}$ & + & + & + & + & + \\
DAX & FAZ & $6 \mathrm{M}$ & + & + & + & + \\
DAX & FAZ & $12 \mathrm{M}$ & + & + & + & + \\
DJI & FAZ & $6 \mathrm{M}$ & + & + & + & + \\
DJI & FAZ & $12 \mathrm{M}$ & + & + & + & + \\
SX5E & FAZ & $6 \mathrm{M}$ & + & + & + & + \\
SX5E & FAZ & $12 \mathrm{M}$ & + & + & + & + \\
\hline
\end{tabular}

+ = Null Hypothesis rejected; DAX = German Stock Market Index; DJI = Dow Jones Industrial Index; SX5E = Euro Stoxx 50; HB = Handelsblatt; FAZ = Frankfurter Allgemeine Zeitung; $12 \mathrm{M}=12$ months; $6 \mathrm{M}=6$ months.

In the case of Hypothesis 2 there are no differences between the subjects of the forecasts and the forecast horizons. In all seven cases, Null Hypothesis 2 has to be rejected. The dispersion of the forecasts (measured against the standard deviation) thus lags behind the dispersion of the actual events.

A uniform picture is also shown with regard to Hypothesis 3. In all seven forecasting areas the slope of the regression line in the prediction-realization diagrams is clearly below one. Null Hypothesis 3 has to be rejected in all seven cases. This means that the rates of change of the stock-market indices are significantly underestimated.

In the case of Hypothesis 4 there are also no relevant differences regarding the subjects of the forecasts or the forecast horizons. In all seven areas, the forecasts prove to be biased. These results are highly significant. In all seven cases, Null Hypothesis 4 has to be rejected.

In Hypothesis 5 there is also a concurring result for all seven forecast groups. Null Hypothesis 5 has to be discarded. The precision of the forecasts does not go significantly beyond that of naïve forecasts.

The findings of Ogburn (1934) are thus fully confirmed in the stock market forecasts which we analyzed. It can certainly be stated that these stock-market analysts systematically underestimate the variability of reality and that the success rate of their forecasts does not extend beyond that of naïve forecasts. Their behavior can be described as "sticky" because their forecasts adhere too strongly to long-term trends in the indices to provide meaningful information about current events.

This study expands on existing research as it is the first of its kind to analyze ex-ante forecasts for the SX5E. The picture obtained is similar to that of the stock indices examined previously. The forecasts are mostly biased and not significantly better than naïve forecasts. About 15 years ago, ex-ante forecasts for the DAX and the DJI were last examined (Table 1). In the meantime, technological progress has led to the emergence of numerous promising new forecasting methods, as discussed in our literature review. However, our results indicate that this has not, at least so far, contributed to a significant increase in the quality of the forecast.

Our findings allow different conclusions to be drawn with regard to the efficient market hypothesis (Fama 1970). On the one hand, the Diebold-Mariano test shows that the forecast quality is poor. This is compatible with the efficient market hypothesis, since no excess returns can be achieved on the basis of the forecasts. On the other hand, the efficient market hypothesis assumes that economic subjects are fully informed. The permanent underestimation of the variability of reality that the prediction-realization diagram reveals should therefore not occur. The acting subjects do not seem to take notice of the discrepancy between their own actions and reality, since no correction of the behavior is made in the subsequent forecasts. 
The forecasters systematically underestimate the variability of reality. Against the background of Mandelbrot's fractal theory, it seems reasonable to conclude that forecasters-as long as they think in terms of "trending" and "mean reversion"-systematically underestimate the Hurst exponent (Mandelbrot 2004) of stock market developments.

Overall, the forecast quality for all three indices is not sufficient to enable an active investment strategy on the basis of the forecasts that is likely to be successful. Moreover, since unusual events (e.g., a sudden drop in an otherwise rising trendline) are seldom successfully forecasted, an active investment strategy based on the forecasts harbors risks that can cause severe financial damage to investors. Thus, we advise private and professional investors to consider a passive investment strategy instead when deciding how to invest their assets.

The path which has to be followed to obtain better stock market forecasts thus becomes clear: analysts have to be more courageous. They need to react to new trends with more flexibility. They have to leave their comfort zone more frequently and stand by assessments which are not necessarily approved of by the majority of their peers. That alone will presumably not suffice to generate reliable stock market forecasts: they will also need to work hard on the quality of their approaches to forecasting. To this end, a variety of interesting approaches are already discussed in the literature, e.g., economic forecasts based on newspaper texts or news from online media and attention to news events (Milas et al. 2021; Kalamara et al. 2020; Ben-Rephael et al. 2017). If analysts want to significantly improve the reliability of their forecasts, there is no alternative but to change their overly cautious, highly conservative, and thus inflexible attitudes.

Finally, our study also has some limitations. First of all, it should be mentioned that we are looking at forecasts for entire stock indices. Even if the forecasters do not manage to successfully predict the development of a stock index, this does not mean that the entire stock market is per se unsuitable for an active investment strategy. It is still conceivable that stocks of individual companies in the index can be predicted successfully. In this case, an active investment strategy based on the forecasts for individual stocks could be very promising. Second, forecasting future events with a six- to twelve-month horizon is a major hurdle. As the forecast quality tends to increase as the horizon decreases (Dua 1988), it is conceivable that, for example, monthly forecasts for the same indices would lead to significantly better results. Last but not least, we analyze the entire time series from beginning to end for each forecaster. Even though this leads to a large sample size, which enables a clearer picture of the forecast quality overall, differences in the forecast quality over time may remain undetected. This could be the case in particular for the forecasts published in Handelsblatt, which extend over a period of 29 years.

Our results provide initial indications that patterns discovered almost 90 years ago that massively deteriorate forecast quality can still be found in stock market forecasts today. We therefore encourage future research efforts to examine whether our results prevail in additional datasets. Furthermore, we believe that deeper analysis of the rationale for conservative forecasting and an assessment of its financial impact on investors are promising areas of research that would deepen our understanding of ex-ante stock market forecasts.

\section{Summary}

We examine forecasts for the German Stock Market Index (DAX), the Dow Jones Industrial Index (DJI), and the Euro Stoxx 50 (SX5E) which were published in the period 1992 to 2020 in the German business newspaper Handelsblatt (HB) and the quality broadsheet the Frankfurter Allgemeine Zeitung (FAZ). These forecasts have a horizon of six and twelve months. The forecasts are from German and international banks such as Deutsche Bank, Goldman Sachs, J.P. Morgan, or BNP Paribas. 
We take up the thoughts of Ogburn (1934), who, on the basis of a small empirical survey, became convinced that forecasters consistently underestimate the variability of the future, and that their forecasting is of a conservative nature. However, we also go beyond this and use some contemporary measures (prediction-realization diagram, test of unbiasedness, Diebold-Mariano test) to test ex-ante forecasts for their success at the time of validity.

Conservative forecasting behavior leads to unusual events being under-represented in forecasts, to the dispersion of the forecasts (as measured by their standard deviation) lagging behind the dispersion of the actual events, and to the extent of the forecasted changes being smaller than the actual changes. The latter aspect is reflected in a flat course of the regression line in the prediction-realization diagram (slope $<1$ ) and thus also leads to failure in the unbiasedness test.

We analyze a total of 2,761 forecasts which are divided up into seven groups according to the subject of the forecast (DAX, DJI, SX5E), the forecast horizon (6 and 12 months), and the source (FAZ, HB). The findings are that in all seven groups (a) unusual events are under-represented in the forecasts, (b) the dispersion of the forecasts lags behind that of actual events, (c) the slope in the regression lines in the prediction-realization diagram is $<1$, (d) the forecasts are biased to a highly significant degree, and (e) that the quality of the forecasts is not significantly better than that of naïve forecasts.

It is more than surprising how closely these stock market forecasts for the years 1992 to 2020 correspond to the characteristics which Ogburn described back in the 1930s. The stock market analysts prove to be too conservative, inflexible, and cautious. If they want to improve the reliability of their forecasts, they should change their conservative and inflexible forecasting behavior and consider promising new approaches and technologies in their forecasting process. For private and professional investors, building active investment strategies based on the insufficient stock market forecasts examined can involve enormous financial risks and is therefore not recommended.

Supplementary Materials: The following are available online at https://www.mdpi.com/article/10 $.3390 / \mathrm{jrfm} 14120593 / \mathrm{s} 1$.

Author Contributions: Data curation, I.F., J.R.J., M.L. and M.S.; Formal analysis, I.F., J.R.J., M.L. and M.S.; Software, I.F.; Visualization, I.F., J.R.J. and M.L.; Writing-original draft, J.R.J., M.L. and M. S.; Writing-review \& editing, I.F., J.R.J., M.L. and M.S. All authors have read and agreed to the published version of the manuscript.

Funding: This research received no external funding.

Data Availability Statement: Our data basis can be accessed at Supplementary Materials.

Acknowledgments: The authors thank the editor and the anonymous reviewers for their constructive comments and useful suggestions, which were very helpful to enhance the manuscript.

Conflicts of Interest: The authors declare no conflict of interest. 
Appendix A. Detailed Summary Statistics on Data Basis

Table A1. Detailed Summary Statistics on DAX, DJI, and SX5E forecasts of our data basis.

\begin{tabular}{|c|c|c|c|c|c|c|c|c|c|}
\hline Source & Subject & Year & $\mathrm{N}$ & $\begin{array}{c}\text { Min } \\
\text { [pts.] }\end{array}$ & $\begin{array}{c}\text { Max } \\
\text { [pts.] }\end{array}$ & $\begin{array}{c}\text { Median } \\
\text { [pts.] }\end{array}$ & $\begin{array}{l}\text { Mean } \\
\text { [pts.] }\end{array}$ & $\begin{array}{c}\text { Actual } \\
\text { [pts.] }\end{array}$ & $\mathrm{N}$ \\
\hline & & & & & Forecas & izon $6 \mathrm{mor}$ & & & \\
\hline HB & DAX & 1992 & NA & NA & NA & NA & NA & NA & 21 \\
\hline & & 1993 & $\mathrm{NA}$ & NA & NA & NA & NA & NA & 25 \\
\hline & & 1994 & NA & $\mathrm{NA}$ & NA & NA & NA & NA & 28 \\
\hline & & 1995 & $\mathrm{NA}$ & $\mathrm{NA}$ & $\mathrm{NA}$ & NA & NA & NA & 33 \\
\hline & & 1996 & NA & NA & NA & NA & NA & NA & 28 \\
\hline & & 1997 & NA & NA & $\mathrm{NA}$ & NA & NA & NA & 34 \\
\hline & & 1998 & $\mathrm{NA}$ & $\mathrm{NA}$ & $\mathrm{NA}$ & NA & NA & NA & 33 \\
\hline & & 1999 & NA & NA & $\mathrm{NA}$ & NA & NA & NA & 34 \\
\hline & & 2000 & NA & NA & $\mathrm{NA}$ & NA & NA & NA & 37 \\
\hline & & 2001 & NA & NA & NA & NA & NA & NA & 33 \\
\hline & & 2002 & NA & NA & $\mathrm{NA}$ & NA & NA & NA & 38 \\
\hline & & 2003 & NA & NA & $\mathrm{NA}$ & NA & NA & NA & 33 \\
\hline & & 2004 & NA & NA & $\mathrm{NA}$ & NA & NA & NA & 34 \\
\hline & & 2005 & NA & NA & $\mathrm{NA}$ & NA & NA & NA & 33 \\
\hline & & 2006 & NA & $\mathrm{NA}$ & $\mathrm{NA}$ & NA & NA & NA & 38 \\
\hline & & 2007 & NA & NA & $\mathrm{NA}$ & NA & NA & NA & 37 \\
\hline & & 2008 & NA & NA & NA & NA & NA & NA & 35 \\
\hline & & 2009 & NA & NA & $\mathrm{NA}$ & NA & NA & NA & 31 \\
\hline & & 2010 & $\mathrm{NA}$ & $\mathrm{NA}$ & $\mathrm{NA}$ & NA & NA & NA & 38 \\
\hline & & 2011 & $\mathrm{NA}$ & $\mathrm{NA}$ & $\mathrm{NA}$ & NA & NA & NA & 39 \\
\hline & & 2012 & $\mathrm{NA}$ & NA & $\mathrm{NA}$ & NA & NA & NA & 37 \\
\hline & & 2013 & NA & NA & $\mathrm{NA}$ & NA & NA & NA & 35 \\
\hline & & 2014 & NA & NA & $\mathrm{NA}$ & NA & NA & NA & 33 \\
\hline & & 2015 & NA & NA & $\mathrm{NA}$ & NA & NA & NA & 36 \\
\hline & & 2016 & NA & NA & $\mathrm{NA}$ & NA & NA & NA & 36 \\
\hline & & 2017 & $\mathrm{NA}$ & NA & $\mathrm{NA}$ & NA & NA & NA & 30 \\
\hline & & 2018 & NA & NA & $\mathrm{NA}$ & NA & NA & NA & 33 \\
\hline & & 2019 & NA & NA & $\mathrm{NA}$ & NA & NA & $\mathrm{NA}$ & 31 \\
\hline & & 2020 & $\mathrm{NA}$ & $\mathrm{NA}$ & NA & $\mathrm{NA}$ & NA & NA & 31 \\
\hline & & & & & Forecas & izon $6 \mathrm{mor}$ & & & \\
\hline FAZ & DAX & 2002 & 14 & 4900 & 6000 & 5650 & 5554 & 4382.56 & 19 \\
\hline & & 2003 & NA & NA & $\mathrm{NA}$ & $\mathrm{NA}$ & $\mathrm{NA}$ & 3220.58 & 17 \\
\hline & & 2004 & 14 & 3600 & 4500 & 4200 & 4184 & 4052.73 & 15 \\
\hline & & 2005 & 15 & 3900 & 4600 & 4400 & 4330 & 4586.28 & 21 \\
\hline & & 2006 & 17 & 5000 & 5950 & 5700 & 5616 & 5683.31 & 20 \\
\hline & & 2007 & 14 & 6200 & 7100 & 6612 & 6623 & 8007.32 & 20 \\
\hline & & 2008 & 14 & 7250 & 8700 & 8066 & 8081 & 6418.32 & 18 \\
\hline & & 2009 & 17 & 3200 & 5700 & 4900 & 4725 & 4808.64 & 17 \\
\hline & & 2010 & 19 & 4800 & 6800 & 6000 & 5875 & 5965.52 & 22 \\
\hline & & 2011 & 19 & 6300 & 8000 & 7300 & 7289 & 7376.24 & 26 \\
\hline & & 2012 & 14 & 4800 & 7000 & 6105 & 6009 & 6416.28 & 22 \\
\hline & & 2013 & 14 & 7000 & 8200 & 7659 & 7618 & 7959.22 & 20 \\
\hline & & 2014 & $\begin{array}{l}17 \\
16\end{array}$ & 8500 & 10,200 & 9660 & 9620 & 9833.07 & 23 \\
\hline & & 2015 & 18 & 8700 & 11,000 & 10,300 & 10,035 & $10,944.97$ & 23 \\
\hline & & 2016 & 17 & 10,200 & 12,250 & 11,400 & 11,388 & 9680.09 & 23 \\
\hline & & 2017 & 19 & 10,600 & 12,400 & 11,500 & 11,494 & $12,325.12$ & 24 \\
\hline & & 2018 & 19 & 12,500 & 15,000 & 13,700 & 13,658 & $12,306.00$ & 25 \\
\hline & & 2019 & NA & $\mathrm{NA}$ & NA & NA & $\mathrm{NA}$ & $12,398.80$ & 24 \\
\hline & & 2020 & 22 & 12,000 & 14,500 & 13,625 & 13,460 & $12,310.93$ & 23 \\
\hline & & & & & Forecas & izon $6 \mathrm{mor}$ & & & \\
\hline FAZ & DJI & 2004 & 10 & 9800 & 11,000 & 10,422 & 10,444 & $10,435.48$ & 10 \\
\hline & & 2005 & 10 & 10,800 & 11,200 & 11,010 & 11,020 & $10,274.97$ & 14 \\
\hline & & 2006 & 14 & 10,000 & 11,800 & 11,223 & 11,196 & $11,150.22$ & 15 \\
\hline & & 2007 & 12 & 12,200 & 14,000 & 12,800 & 12,805 & $13,408.62$ & 14 \\
\hline & & 2008 & 13 & 12,500 & 14,500 & 13,729 & 13,729 & $11,350.01$ & 16 \\
\hline & & 2009 & 14 & 6900 & 10,800 & 9000 & 9000 & 8447.00 & 16 \\
\hline & & 2010 & 16 & 8900 & 12,100 & 10,600 & 10,433 & 9774.02 & 18 \\
\hline & & 2011 & 14 & 10,500 & 13,900 & 11,904 & 11,808 & $12,414.34$ & 16 \\
\hline & & 2012 & 9 & 10,800 & 13,500 & 12,363 & 12,363 & $12,880.09$ & 13 \\
\hline & & 2013 & 8 & 12,100 & 14,000 & 13,487 & 13,381 & $14,909.60$ & 11 \\
\hline & & 2014 & 12 & 14,500 & 16,800 & 16,500 & 16,364 & $16,826.60$ & 14 \\
\hline & & 2015 & 14 & 14,000 & 18,800 & 18,000 & 17,586 & $17,619.51$ & 17 \\
\hline & & 2016 & 12 & 17,500 & 19,000 & 18,123 & 18,245 & $17,929.99$ & 15 \\
\hline & & 2017 & 16 & 18,700 & 21,900 & 19,949 & 19,897 & $21,349.63$ & 17 \\
\hline & & 2018 & 14 & 22,000 & 27,200 & 24,825 & 24,735 & $24,271.41$ & 18 \\
\hline & & 2019 & NA & $\mathrm{NA}$ & NA & NA & NA & $26,599.96$ & 18 \\
\hline & & 2020 & 15 & 27,250 & 29,200 & 28,500 & 28,404 & $25,812.88$ & 17 \\
\hline & & & & & Foreca: & izon $6 \mathrm{mor}$ & & & \\
\hline FAZ & SX5E & 2002 & 14 & 3600 & 4300 & 4062 & 4023 & 3133.39 & 17 \\
\hline & & 2003 & NA & NA & NA & NA & NA & 2419.51 & 15 \\
\hline & & 2004 & 13 & 2500 & 3300 & 2879 & 2879 & 2811.08 & 14 \\
\hline & & 2005 & 15 & 2800 & 3200 & 3050 & 3030 & 3181.54 & 19 \\
\hline & & 2006 & 17 & 3350 & 3800 & 3700 & 3671 & 3648.92 & 18 \\
\hline & & 2007 & 14 & 4000 & 4750 & 4208 & 4215 & 4489.77 & 20 \\
\hline & & 2008 & 14 & 4200 & 4900 & 4508 & 4515 & 3352.81 & 18 \\
\hline & & 2009 & 15 & 1600 & 3000 & 2500 & 2469 & 2401.69 & 17 \\
\hline & & 2010 & 17 & 2400 & 3300 & 2910 & 2896 & 2573.32 & 20 \\
\hline & & 2011 & 17 & 2400 & 3400 & 2950 & 2905 & 2848.53 & 22 \\
\hline & & 2012 & 14 & 1700 & 2600 & 2300 & 2279 & 2264.72 & 22 \\
\hline & & 2013 & 15 & 2162 & 2800 & 2626 & 2626 & 2602.59 & 20 \\
\hline & & 2014 & 15 & 2750 & 3400 & 3250 & 3208 & 3228.25 & 23 \\
\hline & & 2015 & 17 & 2800 & 3550 & 3300 & 3245 & 3424.30 & 22 \\
\hline & & 2016 & 16 & 3145 & 3750 & 3550 & 3543 & 2864.74 & 22 \\
\hline & & 2017 & 18 & 3000 & 3500 & 3271 & 3261 & 3441.88 & 23 \\
\hline & & 2018 & 18 & 3450 & 4050 & 3748 & 3746 & 3395.60 & 23 \\
\hline & & 2019 & NA & NA & $\mathrm{NA}$ & NA & NA & 3473.69 & 23 \\
\hline & & 2020 & 21 & 3400 & 4000 & 3713 & 3713 & 3234.07 & 23 \\
\hline
\end{tabular}

$\mathrm{HB}=$ Handelsblatt; FAZ = Frankfurter Allgemeine Zeitung; DAX = German Stock Market Index; N = Number of forecasts issued; Min = Minimum; Max = Maximum; pts. = points; NA = not available. FAZ = Frankfurter Allgemeine Zeitung; DJI = Dow Jones Industrial Index; SX5E = Euro Stoxx 50; N = Number of forecasts issued; Min = Minimum; Max = Maximum; pts. = points; NA = not available 


\section{Appendix B. Forecasters in the Handelsblatt Newspaper}

1.

2.

3.

4.

5.

6.

7.

8.

9.

10.

11.

12.

13.

14.

15.

16.

17.

18.

19.

20.

21.

22.

23.

24.

25.

26.

27.

28.

29.

30.

31.

32.

33.

34.

35.

36.

37.

38.

39.

40.

41.

42.

43.

44.
ABN Amro

Adca-Bank

B. Metzler Seel. Sohn \& Co.

Baader Bank

Baden-Württembergische Bank

Bank in Liechtenstein

Bank Julius Bär

Bank of America

Bank Sarasin

Bankhaus Ellwanger \& Geiger

Bankhaus Lampe

Bankhaus Metzler

Banque Nationale de Paris

Barclays

Bayerische Landesbank

Bayerische Vereinsbank

Berenberg

Bethmann Bank

BNP Paribas

Cheuvreux

Citi

Commerzbank

Crédit Lyonnais

Credit Suisse

Daiwa Europe (Deutschland)

Dekabank

Deutsche Bank

Donner \& Reuschel

Dresdner Bank

DZ Bank

Fürst Fugger Privatbank

Fürstl. Castell'sche Bank

Goldman Sachs

Gontard \& Metallbank

GZ-Bank

Haspa

Hauck \& Aufhäuser

Helaba

HSBC Trinkaus

HSH Nordbank

IKB

IMI Bank

J. Safra Sarasin

J.P. Morgan
45.

46.

47.

48.

49.

50.

51.

52.

53.

54.

55.

56.

57.

58.

59

60.

61.

62.

63.

64.

65.

66.

67.

68.

69.

70.

71.

72.

73.

74.

75.

76.

77.

78.

79.

80.

81.

82.

83.

84.

85.

86.

87.

88.
Kepler Equities

Kleinwort Benson Research

LB Rheinland-Pfalz

LBB Landesbank Berlin

LBBW

Lehman Brothers

LGT Bank in Liechtenstein

M.M. Warburg \& Co.

Macquarie

Merck Finck \& Co.

Merrill Lynch

Morgan Stanley

National-Bank

NATIXIS

NIBC

Nomura

NordLB

Oddo BHF

Pictet \& Cie.

Postbank

Royal Bank of Scotland

S.G. Warburg

Sal. Oppenheim

Santander

Saxo Bank

SBC Warburg

Schröder Bank

Schröder Münchmeyer Hengst

Schroder Salomon Smith Barney

Schweizerischer Bankverein

SGZ-Bank

Société Générale

SYZ \& Co.

Targobank

UBS

Unicredit HypoVereinsbank

Union Bancaire Priveé

Union Bank of Switzerland

Vereins- und Westbank

Vontobel

VP Bank

Weberbank

WestLB

WGZ Bank 


\begin{tabular}{|c|c|c|c|}
\hline 1. & Adig & 27. & J.P. Morgan \\
\hline 2. & Allianz SE & 28. & Julius Bär \\
\hline 3. & Bankgesellschaft Berlin & 29. & Landesbank Berlin \\
\hline 4. & Bankhaus Lampe & 30. & Landesbank Rheinland-Pfalz \\
\hline 5. & Barclays Capital & 31. & LBBW \\
\hline 6. & Bayern LB & 32. & M.M. Warburg \\
\hline 7. & Berenberg & 33. & Macquarie \\
\hline 8. & BNP Paribas & 34. & Merck Finck Invest \\
\hline 9. & Citigroup & 35. & Merrill Lynch \\
\hline 10. & Commerzbank & 36. & Morgan Stanley \\
\hline 11. & CSFB & 37. & Nomura \\
\hline 12. & Deka Bank & 38. & Nord LB \\
\hline 13. & Deutsche Bank & 39. & Oddo BHF \\
\hline 14. & Deutsche Bank/Postbank & 40. & Postbank \\
\hline 15. & DIT & 41. & Raiffeisen Bank International \\
\hline 16. & Dresdner Bank & 42. & Sal. Oppenheim \\
\hline 17. & DWS & 43. & Santander Asset Management \\
\hline 18. & DZ Bank & 44. & Société Générale \\
\hline 19. & Erste Group & 45. & UBS \\
\hline 20. & Goldman Sachs & 46. & Union Bancaire Privée \\
\hline 21. & Helaba & 47. & Union Investment \\
\hline 22. & HSBC Trinkaus \& Burkhardt & 48. & Vereins- und Westbank \\
\hline 23. & HSH Nordbank & 49. & Weberbank \\
\hline 24. & HVB-Unicredit Bank & 50. & WestLB \\
\hline 25. & IKB & 51. & WGZ Bank \\
\hline
\end{tabular}

\section{References}

Andres, Peter, and Markus Spiwoks. 1999. Forecast Quality Matrix: A Methodological Survey of Judging Forecast Quality of Capital Market Forecasts. Journal of Economics and Statistics 219: 513-42.

Arthur, W. Brian, John H. Holland, Blake LeBaron, Richard Palmer, and Paul Tayler. 1997. Asset pricing under endogenous expectations in an artificial stock market. In The Economy as an Evolving Complex System II. Edited by W. Brian Arthur, Steven N. Durlauf and David A. Lane. Reading: Addison-Wesley.

Atmaz, Adem, Stefano Cassella, Huseyin Gulen, and Fangcheng Ruan. 2021. Contrarians, Extrapolators, and Stock Market Momentum and Reversal. Available online: https:/ /dx.doi.org/10.2139/ssrn.3722540 (accessed on 28 November 2021).

Atsalakis, George S., and Kimon P. Valavanis. 2009. Forecasting stock market short-term trends using a neuro-fuzzy based methodology. Expert systems with Applications 36: 10696-707. [CrossRef]

Bacchetta, Philippe, Elmar Mertens, and Eric Van Wincoop. 2009. Predictability in financial markets: What do survey expectations tell us? Journal of International Money and Finance 28: 406-26. [CrossRef]

Baghestani, Hamid, Mohammad Arzaghi, and Ilker Kaya. 2015. On the Accuracy of Blue Chip Forecasts of Interest Rates and Country Risk Premiums. Applied Economics 47: 113-22. [CrossRef]

Bahrami, Afsaneh, Abul Shamsuddin, and Katherine Uylangco. 2018. Out-of-sample stock return predictability in emerging markets. Accounting \& Finance 58: 727-50.

Ben-Rephael, Azi, Zhi Da, and Ryan D. Israelsen. 2017. It Depends on Where You Search: Institutional Investor Attention and Underreaction to News. Review of Financial Studies 30: 3009-47. [CrossRef]

Benke, Holger. 2006. Was leisten Kapitalmarktprognosen?, Die Sicht eines Stiftungsmanagers. Zeitschrift für das Gesamte Kreditwesen 59: 902-6.

Bertella, Mario A., Felipe R. Pires, Ling Feng, and Harry Eugene Stanley. 2014. Confidence and the Stock Market: An Agent-Based Approach. PLoS ONE 9: e83488. [CrossRef]

Cassella, Stefano, and Huseyin Gulen. 2019. Belief-based Equity Market Sentiment. Available online: https://dx.doi.org/10.2139/ssrn. 3123083 (accessed on 28 November 2021).

Cassella, Stefano, and Huseyin Gulen. 2018. Extrapolation Bias and the Predictability of Stock Returns by Price-Scaled Variables. The Review of Financial Studies 31: 4345-97. [CrossRef]

Chen, Shu-Heng, and Ya-Chi Huang. 2008. Risk preference, forecasting accuracy and survival dynamics: Simulations based on a multi-asset agent-based artificial stock market. Journal of Economic Behavior E Organization 67: 702-17.

Chen, Yi-ting, and Kendro Vincent. 2016. The Role of Momentum, Sentiment, and Economic Fundamentals in Forecasting Bear Stock Market. Journal of Forecasting 35: 504-27. [CrossRef]

Cowles, Alfred. 1933. Can stock market forecasters forecast? Econometrica: Journal of the Econometric Society 1: 309-24. [CrossRef] 
De Bondt, Werner P. 1993. Betting on trends: Intuitive forecasts of financial risk and return. International Journal of Forecasting 9: 355-71. [CrossRef]

Diebold, Francis X., and Robert S. Mariano. 1995. Comparing Predictive Accuracy. Journal of Business and Economic Statistics 13: $253-63$.

Dimson, Elroy, and Paul Marsh. 1984. An analysis of brokers' and analysts' unpublished forecasts of UK stock returns. The Journal of Finance 39: 1257-92. [CrossRef]

Dua, Pami. 1988. Multiperiod forecasts of interest rates. Journal of Business E Economic Statistics 6: 381-84.

Fama, Eugene. 1970. Efficient Capital Markets: A Review of Theory and Empirical Work. The Journal of Finance 25: 383-417. [CrossRef]

Fassas, Athanasios, Stephanos Papadamou, and Dimitrios Kenourgios. 2021. Evaluating survey-based forecasts of interest rates and macroeconomic variables. Journal of Economic Studies. [CrossRef]

Filiz, Ibrahim, Jan René Judek, Marco Lorenz, and Markus Spiwoks. 2021. Interest rate forecasts in Latin America. Journal of Economic Studies. [CrossRef]

Filiz, Ibrahim, Thomas Nahmer, Markus Spiwoks, and Kilian Bizer. 2019. The accuracy of interest rate forecasts in the Asia-Pacific region: Opportunities for portfolio management. Applied Economics 51: 6309-32. [CrossRef]

Fraser, Patricia, and Ronald MacDonald. 1993. The efficiency of CAC stock price forecasts: A survey based perspective. Revue Économique 44: 991-1000.

Friend, Irwin, and Douglas Vickers. 1965. Portfolio selection and investment performance. The Journal of Finance 20: 391-415. [CrossRef]

Fujiwara, Ippei, Hibiki Ichiue, Yoshiyuki Nakazono, and Yosuke Shigemi. 2013. Financial markets forecasts revisited: Are they rational, stubborn or jumpy? Economics Letters 118: 526-30. [CrossRef]

Goyal, Amit, Ivo Welch, and Athanasse Zafirov. 2021. A Comprehensive Look at the Empirical Performance of Equity Premium Prediction II. Available online: https:/ / dx.doi.org/10.2139/ssrn.3929119 (accessed on 28 November 2021).

Granger, Clive W., and Paul Newbold. 1974. Spurious regressions in econometrics. Journal of Econometrics 2: 111-20. [CrossRef]

Greenwood, Robin, and Andrei Shleifer. 2014. Expectations of Returns and Expected Returns. The Review of Financial Studies 27: 714-46. [CrossRef]

Guo, Hui. 2006. On the out-of-sample predictability of stock market returns. The Journal of Business 79: 645-70. [CrossRef]

Hein, Oliver, Michael Schwind, and Markus Spiwoks. 2012. Network Centrality and Stock Market Volatility: The Impact of Communication Topologies on Prices. Journal of Finance and Investment Analysis 1: 199-232.

Kalamara, Eleni, Arthur Turrell, Chris Redl, George Kapetanios, and Sujit Kapadia. 2020. Making Text Count: Economic Forecasting Using Newspaper Text. Bank of England Research Paper Series 865: 1-49. [CrossRef]

Kandasamy, Narayanan, Sarah N. Garfinkel, Lionel Page, Ben Hardy, Hugo D. Critchley, Mark Gurnell, and John M. Coates. 2016. Interoceptive Ability Predicts Survival on a London Trading Floor. Scientific Reports 6: 32986. [CrossRef]

Kazak, Ekaterina, and Winfried Pohlmeier. 2019. Testing out-of-sample portfolio performance. International Journal of Forecasting 35: 540-54. [CrossRef]

Krichene, Hazem, and Mhamed-Ali El-Aroui. 2018. Artificial stock markets with different maturity levels: Simulation of information asymmetry and herd behavior using agent-based and network models. Journal of Economic Interaction and Coordination 13: 511-35. [CrossRef]

Kunze, Frederik, Markus Spiwoks, Kilian Bizer, and Torsten Windels. 2018. The usefulness of oil price forecasts-Evidence from survey prediction. Managerial and Decision Economics 39: 427-46. [CrossRef]

Kunze, Frederik, Christoph Wegener, Kilian Bizer, and Markus Spiwoks. 2017. Forecasting European interest rates in times of financial crisis-What insights do we get from international survey forecasts? Journal of International Financial Markets, Institutions and Money 48: 192-205. [CrossRef]

Lakonishok, Josef. 1980. Stock market return expectations: Some general properties. The Journal of Finance 35: 921-31. [CrossRef]

Lofthouse, Stephen. 1996. Why Active Investment Management is Popular: The Psychology of Extraordinary Beliefs. Journal of Interdisciplinary Economics 7: 41-61. [CrossRef]

Mallikarjuna, Mejari, and R. Prabhakara Rao. 2019. Evaluation of forecasting methods from selected stock market returns. Financial Innovation 5: 1-16. [CrossRef]

Mandelbrot, Benoit. 2004. The (Mis)Behavior of Markets—A Fractal View of Risk, Ruin and Reward. New York: Basic Books, pp. $186-95$.

Maxwell, Michael, and Gary van Vuuren. 2019. Active investment strategies under tracking error constraints. International Advances in Economic Research 25: 309-22. [CrossRef]

Miah, Fazlul, Ahmed Ali Khalifa, and Shawkat Hammoudeh. 2016. Further evidence on the rationality of interest rate expectations: A comprehensive study of developed and emerging economies. Economic Modelling 54: 574-90. [CrossRef]

Milas, Costas, Theodore Panagiotidis, and Theologos Dergiades. 2021. Does It Matter Where You Search? Twitter versus Traditional News Media. Journal of Money, Credit and Banking 153: 1757-95. [CrossRef]

Mincer, Jacob A., and Victor Zarnowitz. 1969. The Evaluation of Economic Forecasts. In Economic Forecasts and Expectation. Edited by Jacob Mincer. New York: Columbia University Press, pp. 3-46.

Neely, Christopher J., David E. Rapach, Jun Tu, and Guofu Zhou. 2014. Forecasting the equity risk premium: The role of technical indicators. Management Science 60: 1772-91. [CrossRef]

Nyberg, Henri. 2013. Predicting bear and bull stock markets with dynamic binary time series models. Journal of Banking $\mathcal{E}$ Finance 37: 3351-63.

Ogburn, William F. 1934. Studies in Prediction and the Distortion of Reality. Social Forces 13: 224-29. [CrossRef] 
Oliver, Nelson, and Mehmet Pasaogullari. 2015. Interest Rate Forecasts in Conventional and Unconventional Monetary Policy Periods. Economic commentary 5: 1-4. [CrossRef]

Ortiz-Teran, Elena, Tomas Ortiz, Agustin Turrero, and Joaquin Lopez-Pascual. 2019. Neural implications of investment banking experience in decision-making under risk and ambiguity. Journal of Neuroscience, Psychology, and Economics 12: 34-44. [CrossRef]

Pierdzioch, Christian. 2015. A note on the directional accuracy of interest-rate forecasts. Applied Economics Letters 22: 1073-77. [CrossRef]

Ponta, Linda, and Silvano Cincotti. 2018. Traders' Networks of Interactions and Structural Properties of Financial Markets: An Agent-Based Approach. Hindawi Complexity 2018: 1-9. [CrossRef]

Rajab, Sharifa, and Vinod Sharma. 2019. An interpretable neuro-fuzzy approach to stock price forecasting. Soft Computing 23: 921-36. [CrossRef]

Ramnath, Sundaresh, Steve Rock, and Philip Shane. 2008. The Financial Analyst Forecasting Literature: A Taxonomy with Suggestions for Further Research. International Journal of Forecasting 24: 34-75. [CrossRef]

Spiwoks, Markus, and Oliver Hein. 2007. Die Währungs-, Anleihen- und Aktienmarktprognosen des Zentrums für Europäische Wirtschaftsforschung. AStA Wirtschafts- und Sozialstatistisches Archiv 1: 43-52. [CrossRef]

Spiwoks, Markus. 2004. The Usefulness of ZEW Stock Market Forecasts for Active Portfolio Management Strategies. Journal of Economics and Statistics 224: 557-78.

Spiwoks, Markus, Zulia Gubaydullina, and Oliver Hein. 2015. Trapped in the Here and Now - New Insights into Financial Market Analyst Behavior. Journal of Applied Finance and Banking 5: 29-50.

Theil, Henri. 1958. Economic Forecasts and Policy. Amsterdam: North Holland Publishing Company.

Theissen, Erik. 2007. An analysis of private investors' stock market return forecasts. Applied Financial Economics 17: 35-43. [CrossRef]

Wald, Abraham. 1943. Tests of Statistical Hypotheses Concerning Several Parameters When the Number of Observations is Large. Transactions of the American Mathematical Society 54: 426-82. [CrossRef]

Welch, Ivo, and Amit Goyal. 2008. A comprehensive look at the empirical performance of equity premium prediction. The Review of Financial Studies 21: 1455-508. [CrossRef]

Werner, Natalie S., Katharina Jung, Stefan Duschek, and Rainer Schandry. 2009. Enhanced cardiac perception is associated with benefits in decision-making. Psychophysiology 46: 1123-29. [CrossRef] [PubMed]

Wooldridge, J. M. 2002. Econometric Analysis of Cross Section and Panel Data. Cambridge: MIT Press.

Yang, Xinhui, Jie Zhang, and Qing Ye. 2020. Tick size and market quality: Simulations based on agent-based artificial stock markets. Intelligent Systems in Accounting, Finance and Management 27: 125-41. [CrossRef] 